\title{
Sonlu Elemanlar Hesaplama Parametrelerinin Sac Metal Şekillendirme Simülasyon Süresi ve Hassasiyetine Etkisinin Tespiti
}

\author{
Hüseyin Vatansever ${ }^{1}$, Emre Esener $^{* 2}$ \\ ${ }^{1}$ Bilecik Şeyh Edebali Üniversitesi, Mühendislik Fakültesi, Makine Mühendisliği Bölümü, Bilecik, Türkiye (ORCID: 0000-0002-1760-0008) \\ *2 Bilecik Şeyh Edebali Üniversitesi, Mühendislik Fakültesi, Makine Mühendisliği Bölümü, Bilecik, Türkiye (ORCID: 0000-0001-5854-4834)
}

(İlk Geliş Tarihi 18 Nisan 2019 ve Kabul Tarihi 24 Mayıs 2019)

(DOI: 10.31590/ejosat.555491)

ATIF/REFERENCE: Vatansever, H. \& Esener, E. (2019). Sonlu Elemanlar Hesaplama Parametrelerinin Sac Metal Şekillendirme Simülasyon Süresi ve Hassasiyetine Etkisinin Tespiti. Avrupa Bilim ve Teknoloji Dergisi, (16), 92-108.

\section{$\ddot{O} \mathbf{z}$}

Bir sonlu elemanlar analizinin en önemli çıktısı tahmin hassasiyetidir. Tahmin hassasiyetine etki eden parametreler prosesten bağımsız durumda olan ve modelleme adımlarını oluşturan sonlu elemanlar hesaplama parametreleridir. Simülasyon hassasiyetinin yanı sıra özellikle seri imalat endüstrisi açısından simülasyon çözüm süresi bir diğer kritik parametredir. Sonlu elemanlar analizlerinde verimin yükseltilebilmesi için hassasiyetten ödün vermeden minimum sürede çözümün tamamlanması gerekmektedir. Bu kapsamda hesaplama parametrelerinin iyi analiz edilip hassasiyete ve simülasyon süresine etkilerinin tespit edilmesi önem arz etmektedir. Yapılan çalışmanın amacı, sonlu elemanlar hesaplama parametrelerinin sac metal şekillendirme simülasyon süresi ve hassasiyetine etkisinin tespit edilmesidir. Bu kapsamda non-lineer sac metal şekillendirme simülasyonlarında hesaplama parametrelerinden simetri durumu, eleman boyutu, eleman formülasyonu, integrasyon nokta sayısı, zaman adım aralığı, adaptiv ağ yapısı derecesi, şekillendirme hızı etkisi, plastisite modeli ve çözümün gerçekleştirildiği sistemin çekirdek sayısı olmak üzere geniş bir küme analiz edilmiştir. Sac metal şekillendirme prosesi olarak malzeme şekillendirilebilirlik özelliklerinin belirgin şekilde analiz edilebildiği kare kutu çekme prosesi tercih edilmiştir. Malzeme olarak ise gelişmiş yüksek mukavemetli çeliklerden TRIP600 kullanılmıştır. Sonlu elemanlar analizi hassasiyetinin belirlenmesi amacıyla şekillendirme kuvvetinin zımba ilerleme mesafesine göre değişimini temsil eden deneysel eğri referans alınmıştır. Sonrasında belirlenen parametrelerin değişsen değerlerinde simülasyonlar gerçekleştirilmiş olup her parametrenin hassasiyete ve çözüm süresine etkisi tespit edilmiştir. Bu kapsamda deneysel eğrinin tahmin edilebilirliği her parametre için incelenmiştir. Yapılan simülasyon sonucunda süreye etki eden en baskın parametrenin sonlu elemanlar modelinin simetri durumu olduğu tespit edilmiştir. Parametre kümelerinden süreyi minimize eden parametrelerin tespiti sonrasında elde edilen en verimli simülasyon sonucunda başlangıç durumuna göre hassasiyetten ödün vermeden zamandan $\% 90$ oranında tasarruf edilmiştir. Başlangıçta 2514 saniye süren simülasyon aynı hassasiyeti içerecek şekilde 94 saniyede tamamlanmıştır.

Anahtar Kelimeler: Sonlu elemanlar analizi, Sac metal şekillendirme, Hesaplama parametreleri, Hassasiyet, Simülasyon süresi.

\section{Determining The Effect of Finite Element Calculation Parameters on Sheet Metal Forming Simulation Time and Accuracy}

\begin{abstract}
The most significant output of a finite element analyses is the prediction accuracy. Effective parameters on the prediction accuracy can be defined as finite element calculation parameters which are independent of the process and generates the modeling stages. Besides the prediction accuracy, simulation time is another critical parameter especially in terms of mass production industry. Simulation time must be minimized without compromising prediction accuracy for increasing efficiency of the finite element
\end{abstract}

\footnotetext{
${ }^{1}$ Sorumlu Yazar: Bilecik Şeyh Edebali Üniversitesi, Mühendislik Fakültesi, Makine Mühendisliği Bölümü, Bilecik, Türkiye, ORCID: 0000-00015854-4834, emre.esener@bilecik.edu.tr
} 


\section{European Journal of Science and Technology}

analyses. In this context, calculation parameters must be well defined and determination on simulation time and accuracy must be analyzed. The aim of this study is to determine the effects of finite element calculation parameters on sheet metal forming simulation time and accuracy. In this context, symmetry condition, element size, element formulation, number of integration points, time step size, adaptivity level, forming speed, plasticity model, and number of cores in CPU are analyzed as finite element calculation parameters. Square cup drawing is used as sheet metal forming process due to its capability to analyzing formability properties of materials. TRIP600 advanced high strength steel is used as material. Forming force vs. punch stroke curve is used as experimental result for validating the finite element simulation prediction accuracy. Then, simulations with determinated parameters were performed with selected values and effects of these parameters on simulation time and accuracy are contained. As a result of simulations, symmetry condition is obtained as the dominant parameter on simulation time. Simulation with productive parameters minimized the simulation time as $90 \%$. Preliminarily, simulation time determined as 2514 seconds and as a result of this study simulation time is decreased to 94 seconds.

Keywords: Finite element analysis, Sheet metal forming, Calculation parameters, Accuracy, Simulation time.

\section{Giriş}

Sac metaller ağırlık/dayanım oranlarının iyi olması nedeniyle birçok sektörde sıklıkla kullanılan malzeme grubu olarak değerlendirilmektedir. İnce malzemelerin ( 0,4-6 mm) kalıp takımları vasıtası ile plastik şekil değiştirme mantığı çerçevesinde form değiştirme işlemleri sac metal şekillendirme olarak isimlendirilmektedir. Düşük ağılıklı ve yüksek mukavemetli malzemeler olmaları nedeniyle çarpışma ve ağırlıkça kritik parçaların yer aldığı otomotiv sektörü sac metallerin ana endüstrilerinden kabul edilmektedir. Seri üretimin hakim olduğu endüstrilerde üretim hızı oldukça kritik olduğundan üretim öncesi malzeme seçimi, kalıp takım yüzeylerinin geliştirilmesi ve proses tasarımı adımlarının da hızlı bir şekilde gerçekleştirilmesi gerekmektedir. Bu süreçlerin deneme/yanılma yöntemiyle gerçekleştirilmesi gerek maliyet gerekse de zaman açısından dezavantajlı konumdadır. Bu nedenle proses tasarımı aşamasında günümüzde bilgisayar destekli mühendislik araçları kullanılmaktadır. Sonlu elemanlar yöntemi ise bu araçlar arasında en sık kullanılan yöntem olarak öne çıkmaktadır [1]. Sonlu elemanlar analizi yöntemi temel olarak karmaşık geometrilerin basit sonlu elemanlarla temsil edilmesi sonucunda dış yükler altında gerilme ve deplasmanların hesaplanması olarak tanımlanabilmektedir.

Sac metal şekillendirme prosesleri sırasında ve sonrasında ürün geometrilerinin karmaşık olmasından ve ince malzemelerle çalışılmasından dolayı birçok hata ile karşılaşılmaktadır. Bu hatalar genellikle yırtılma, kırışma, kulaklanma ve şekil bozukluğu olarak ortaya çıkmaktadır. Oluşan hataların ana kaynağı genellikle proses parametreleridir. Yapılan literatür çalışmaları genellikle parça tutucu kuvvet, kalıp hızı, kalıp geometrisi ve sürtünme koşullarının sac metal şekillendirme hataları üzerinde baskın etkilerinin bulunduğunu ortaya koymaktadır [2-5]. Bir sac metalin bahsedilen hatalar olmaksızın şekil alabilme kabiliyetine şekillendirilebilirlik denilmektedir. Kalıp takımlarının şekillendirme yüzeyleri hatasız ürün formunu yakabilecek şekilde geliştirilmelidir. Bu kapsamda malzemenin şekillendirilebilirliği proses parametreleri açısından analiz edilmelidir. CAD ortamında geliştirilen ilk kalıp yüzeyleri sonlu elemanlar analizi kullanılarak malzemelerin form alabilme kabiliyetlerinin ve proses parametrelerinin bu forma etkisinin incelenmesi sonucunda güncellenmekte olup bu işlem iteratif bir şekilde sağlanmaktadır. Her bir iterasyon adımı bir sonlu elemanlar analizini ya da optimizasyon adımını temsil etmektedir [6]. Sac metal şekillendirme simülasyonları büyük şekil değişimleri içerdiğinden ve temas yüzlerinin bulunmasından ötürü yüksek non-lineerlik barındırmaktadır.

Bir sonlu elemanlar analizinin en önemli çıktısı tahmin hassasiyetidir. Tahmin hassasiyeti sonlu elemanlar sonucunda elde edilen sonuçların gerçek deneysel parçaya ne kadar yakınsadığının temsil durumudur. Bu nedenle sonlu elemanlar analizlerindeki proses koşulları gerçek koşullarla aynı tutularak simülasyonlar gerçekleştirilmektedir. Bu durumda tahmin hassasiyetine etki eden parametreler prosesten bağımsız durumda olan ve modelleme adımlarını oluşturan sonlu elemanlar hesaplama parametreleridir. Modelleme adımında hesaplama adımlarını oluşturan hesaplama parametreleri sınır koşulları, geometriyi temsil eden eleman bilgileri ve malzemenin plastik davranışını modelleyen plastisite modelleri olarak tanımlanabilmektedir. İlgili parametrelerin belirlenme şekli ve seçilme nedenleri simülasyon hassasiyetine doğrudan etki etmektedir [7]. Simülasyon hassasiyeti üzerine yapılan çalışmalar göz önüne alındığında hesaplama parametrelerinin tahmin hassasiyetine etkisi açıkça görülmektedir [8-11]. Literatürde yapılan çalışmalar genellikle eleman boyutunun ve plastisite modellerinin etkileri üzerine yoğunlaşmıştır [12-15].

Simülasyon hassasiyetinin yanı sıra özellikle seri imalat endüstrisi açısından simülasyon çözüm süresi bir diğer kritik parametredir. Yukarıda bahsedildiği üzere sac metal şekillendirme simülasyonları yüksek non-lineerlik barındırdığından modelleme ve çözüm aşamaları da karmaşık adımlar içermektedir. Karmaşık geometrilerde gerçekleştirilen sac metal şekillendirme simülasyonları karmaşıklık derecesine bağlı olarak saatler hatta günler sürebilmektedir $[16,17]$. Seri üretim açısından bu tarz simülasyonlar zaman açısından ciddi kayıplara yol açabilmektedir. Endüstride ise simülasyonlar genellikle tecrübelere dayalı oluşturulmuş talimatlar ile gerçekleştirilmektedir. Literatürde ise simülasyon süresi açısından yapılmış çalışmalar oldukça kısıtlıdır [18-20]. Sonlu elemanlar analizlerinde verimin yükseltilebilmesi için hassasiyetten ödün vermeden minimum sürede çözümün tamamlanması gerekmektedir. Bu kapsamda hesaplama parametrelerinin iyi analiz edilip hassasiyete ve simülasyon süresine etkilerinin tespit edilmesi önem arz etmektedir.

$\mathrm{Bu}$ çalışmada, sac metal şekillendirme sonlu elemanlar analizlerinde hesaplama parametrelerinin simülasyon hassasiyeti ve çözüm süresine etkileri analiz edilmiştir. Hesaplama parametrelerinden sınır koşulları, çözüm adımları, plastisite modelleri ve eleman bilgilerini içeren parametrelerin geniş bir kümesi tek bir proses üzerinde analiz edilmiş ve her bir parametrenin hem hassasiyete hem 
de simülasyon süresine etkileri tespit edilmiştir. Prosese ait deneysel sonuçlar hassasiyet sağlaması için kullanılırken çözüm süresini minimize eden parametreler tespit edilmiş olup çözüm süresi açısından büyük derecede iyileştirme sağlanmıştır.

\section{Sonlu Elemanlar Hesaplama Parametreleri}

Çalışmanın bu adımında sonlu elemanlar hesaplama parametrelerinin tanımlanması ve değerlendirilmesi gerçekleştirilmiş ve yapılan çalışmada kullanılan tüm parametrelerin modelleme ve çözüm aşamalarındaki işlevleri açıklanmıştır. Sonlu elemanlar hesaplama parametrelerinden simetri durumu, eleman boyutu, eleman formülasyonu, integrasyon nokta sayısı, zaman adım aralığı, adaptiv ağ yapısı derecesi, hız etkisi, plastisite modeli ve çözümün gerçekleştirildiği sistemin çekirdek sayısı olmak üzere geniş bir küme analiz edilmiştir.

Bir sonlu elemanlar analizinde CAD ortamından alınan geometrilere uygulanan ilk işlem genelde ağ yapısının oluşturulmasıdır. Bir sonlu elemanlar ăg yapısı eleman ve dügüm noktalarından meydana gelmektedir. Burada, eleman geometriyi temsil eden sonlu parçacıkları, düğüm noktası ise bu parçacıkların köşe noktalarını temsil etmektedir. Sonlu elemanlar analizlerinde kullanılabilecek eleman tipleri genellikle 1-Boyutlu kiriş elemanlar, 2-Boyutlu kabuk ya da membran elemanlar ve 3-Boyutlu kübik elemanlardır. Sac metal şekillendirme prosesleri bir düzlem gerilme problemi olduğundan ve kalıp takımlarının yalnızca form verme yüzeylerinin kritik olmasından ötürü geometriler yüzey olarak modellenir. Bu nedenle sac metal şekillendirme işlemlerinde eleman tipi olarak çoğunlukla kabuk eleman kullanılmaktadır [21]. Simülasyonlarda geometrileri temsil eden elemanların bir diğer önemli özelliği ise eleman boyutudur. Sistemi temsil eden eleman sayısının artması çözülecek diferansiyel denklem sayısını arttırdığından bu durumun paralelinde çözüm süresini de arttırmaktadır. Literatürde yapılan çalışmalar incelendiğinde eleman boyutunun küçülmesi çözüm hassasiyeti açısından genellikle olumlu bir etki meydana getirmektedir [22,23]. Özellikle geometrilerin eğrisel bölgelerinin temsili açısından bu bölgelerde eleman boyutunun düzlemsel bölgelere göre daha küçük seçilmesi gerekmektedir.

Sonlu elemanlar analizlerinde eleman boyutu etkisinin bir diğer değerlendirme şekli ise ağ adaptasyonudur. Bu durum adaptivite olarak değerlendirilir ve sonlu elemanlar hesaplama parametresi olarak adaptivite derecesi kullanılılır. A $\breve{g}$ adaptasyonunda temel mantık, özellikle eğilme deformasyonuna uğrayan bölgelerde (radyüs, süzdürme çubuğu v.b.) çözüm sırasında başlangıç ağ yapısının küçültülerek daha hassas sonuçların alınmasıdır. Bu kapsamda örneğin bir dörtgen eleman birinci adaptasyon seviyesinde dörde bölünür ve her seviyede bu durum kendi içinde bölünmelerle devam eder. Çözüm sonrasında başlangıç ağ yapısının ağ adaptasyonu sonrasında değiştiği gözlemlenmektedir. Ağ adaptasyonunun şematik gösterimi ve ağ adaptasyon uygulamasına ait bir örnek sirasıyla Şekil 1 ve Şekil 2'de görülmektedir.

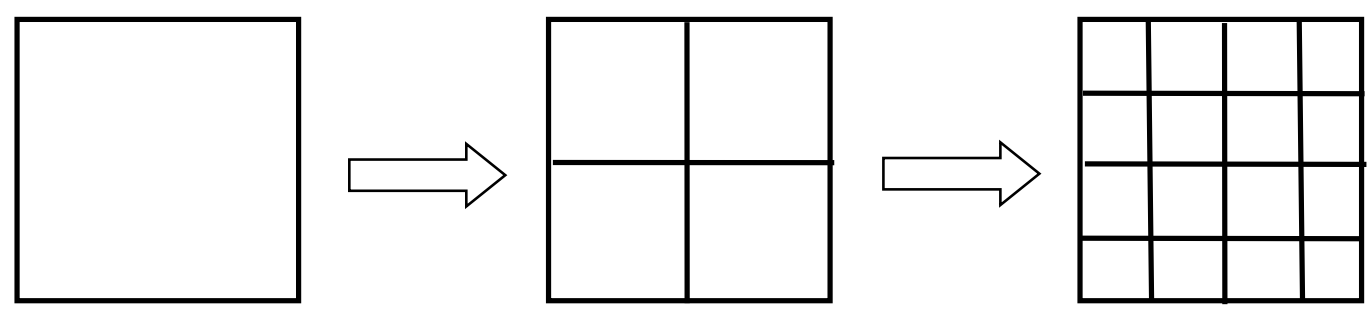

Şekil 1. Ă̆ Adaptasyonu Şematik Gösterimi

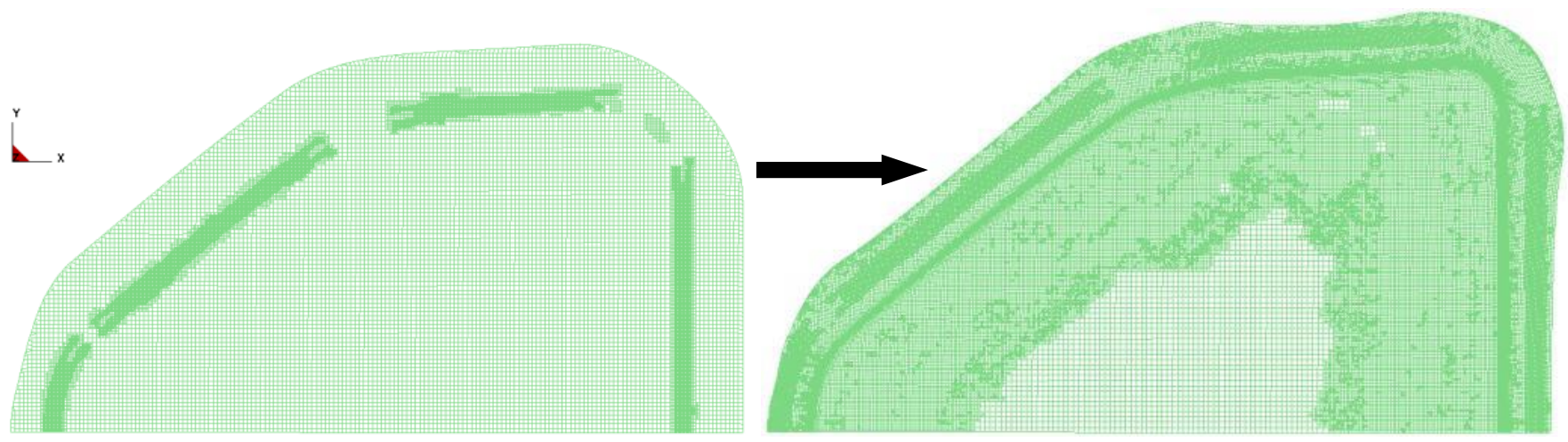

Şekil 2. Ăg Adaptasyonu Durumuna Bir Örnek

Eleman açısından bir diğer önemli özellik ise elemanın çözüm şeklini belirleyen eleman formülasyonudur. Kabuk elemanlar genellikle Hughes-Liu (HL), Belytschko-Tsay (BT) ve Tam integrasyonlu eleman formülasyonları ile modellenmektedirler [24]. Bu formülasyonlardan en eskisi 1981 yılında ortaya atılan Hughes-Liu [25] formülasyonudur. HL kabuk elemanlarda, eleman yapıs1 rijit hareketlerde gerinim üretmediği için birçok uygulamada sonlu gerinim hesaplaması rahatlıkla yapılabilmektedir. Ayrıca basit yapısından dolayı hesaplanma kolaylı̆̆ı sağlamaktadır ve sonlu enine kayma gerinimlerini üzerinde barındırmaktadır Bunun yanı sıra 
European Journal of Science and Technology

kabuk elemanlarda kalınlık yönünde incelme hesabı yapılabilmesine olanak sağlamaktadır. Belytschko-Tsay kabuk eleman formülasyonu ise 1984 yılında ortaya atılmıştır [26]. BT kabuk elemanı, HL kabuk elemanına göre daha avantajlıdır. Bunun nedeni BT kabuk elemanlar HL kabuk elemanlara göre daha az sayıda işleme gereksinim duymaktadır ve dolayısı ile çözüm süresini oldukça kısaltmaktadır ve hesaplama maliyetini düşürmektedir. Örneğin 5 integrasyon noktalı bir kabuk eleman için Hughes-Liu 4050 matematiksel operasyona ihtiyaç duyarken aynı durumda Belytschko-Tsay formülasyonu 725 matematiksel operasyona ihtiyaç duymaktadır [27]. BT kabuk elemanı dönel koordinat sistemi üzerine oturtulmuş hız-gerinim hesaplama metodunu kullanan bir elemandır. Eleman koordinat sistemi kullanılması lineer olmayan hesaplama karmaşasında hesaplama kolaylığı sağlarken hıza bağlı gerinim özelliğinin olması Cauchy gerilmesiyle benzerlikler göstermektedir Tam integrasyonlu kabuk elemanlar ise, kilitlenme problemlerini azaltmak ve düzlemsel eğme davranışını arttırmak için gerinim interpolasyonu kabulü yapar. Lokal koordinat sistemi kullanır. Bu koordinat sistemi malzemedeki rijit cisim hareketini tanımlayabilmek için malzeme ile birlikte dönmektedir. Lokal koordinat sistemi BT kabuk elemanınkine benzerdir. İki temel vektör eleman merkezindeki kabuk yüzeyine teğet, üçüncü vektör ise bu yüzeye normal durumundadır. Tam integrasyonlu kabuk elemanlar, BT kabuk elemanları gibi hızlı çözüm yapabilen bir eleman formülasyonudur.

Kabuk elemanlar düzlem gerilme problemlerini modelleme amaçlı olduklarından temsil ettikleri geometriler yüzey modelleri olarak karşımıza çıkmaktadır. Sac metal şekillendirme proseslerinde incelme oldukça kritik bir parametre olduğundan kalınlık yönündeki gerilme dağılımına ihtiyaç duyulmaktadır. Kabuk eleman formülasyonları kalınlık yönündeki gerilme dağılımlarını integrasyon nokta sayısı ile hesaplamaktadır. İntegrasyon nokta sayısı kabuk elemanın kalınlık yönünde kaç katmanda incelendiğinin temsilidir. Integrasyon nokta sayısının bir eleman üzerinden gösterimi Şekil 3 'te görülmektedir. Şekilden de görüldügü üzere gerilme hesapları kalınlık yönündeki integrasyon noktaları kullanılarak gerçekleştirilmektedir.

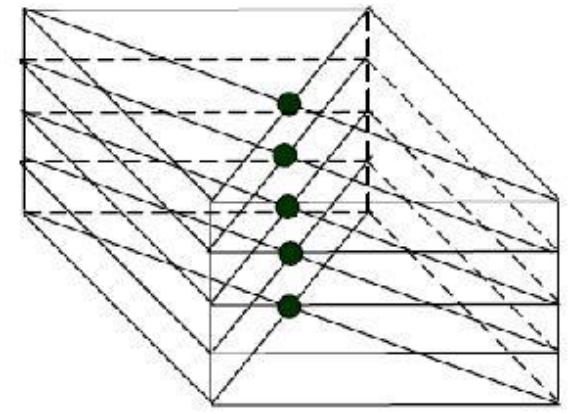

(a)

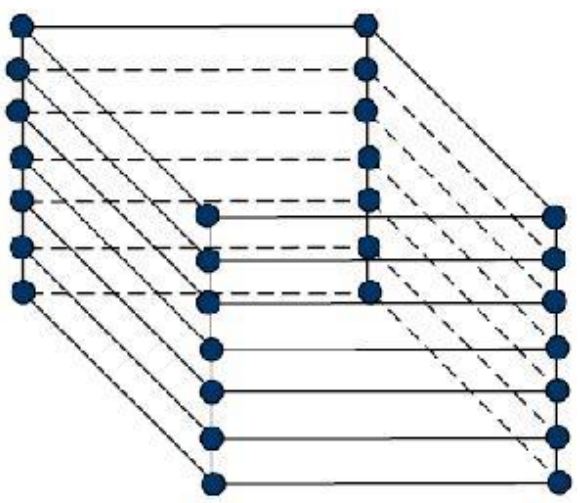

(b)

Şekil 3. Kabuk Eleman İ̧̧in (a) 5 Katmanda Sadeleştirilmiş (b) 7 Katmanda Tam Çözüm İçin Hesaplama Noktaları [28]

Bir diğer sonlu elemanlar parametresi ise zaman adımı büyüklüğüdür. Zaman adımı büyüklüğü şu şekilde hesaplanabilir,

$$
\Delta t=\frac{L}{c}
$$

Burada, $\Delta \mathrm{t}$, zaman adv́mú büyüklüğünü, L sonlu elemanlar ağ yapısındaki en küçük elemanın kenar uzunluğunu, c ise ses hızını temsil etmektedir. Ses hızı ise şu şekilde hesaplanabilir,

$$
C=\sqrt{\frac{E}{\rho_{0}\left(1-v^{2}\right)}}
$$

Burada, E elastisite modulünü, $\rho_{0}$ malzeme yoğunluğunu, v ise Poisson oranını temsil etmektedir. Zaman adımı büyüklüğü toplam zaman adımının bulunmasında kullanılır ve sonlu elemanlar analizlerinin çözüm süresini etkileyen önemli bir parametredir.

Sonlu elemanlar analizlerinin çözüm süresini kısaltmak adına geometrisinde simetri bulunan kalıp takımları yarı model ya da çeyrek model olarak tasarlanabilirler. Bunun için simetri sınır koşullarının tanımlanması gerekmektedir. Simetrinin sağlandığı eksen üzerindeki düğüm noktalarının uzaydaki serbestlik derecelerinin kısıtlanması ile simetri davranışı modellenebilmektedir. Çözüm süresine etki eden bir diğer parametre de deformasyon hızıdır. Bu kapsamda şekillendirme sırasında kalıp hızının etkisi hem simülasyon süresine hem de simülasyon tahmin hassasiyetine doğrudan etki etmektedir.

Hesaplama parametreleri açısından malzemenin plastik davranışını modelleyen plastisite modelleri hesaplama adımında hassasiyete doğrudan etki eden bir parametredir bunun paralelinde her bir plastisite modelinin çözüm adımları farklı olduğundan çözüm süresi de etkilenmektedir. Plastisite modelleri genellikle yaptıkla kabullere göre gruplandırılırlar. Bu gruplar, izotropik malzeme-izotropik pekleşme, anizotropik malzeme-izotropik pekleşme ve anizotropik malzeme-kinematik pekleşme olarak isimlendirilmektedir. Yapılan çalışma kapsamında izotropik malzeme-izotropik pekleşme grubundan Holloman [29] denklemi temelli Power law plastisite modeli, anizotropik malzeme-izotropik pekleşme grubundan Hill-48 [30] ve Barlat-89 [31] plastisite modelleri ve anizotropik malzeme-kinematik pekleşme grubundan Yoshida-Uemori [32] plastisite modelleri kullanılmıştır. Plastisite modelleri değerlendirildiğinde; 

yazilabilir.

Power law plastisite modeli için Holloman ifadesinde gerilme ve plastik gerinim arasındaki ilişki Denklem (3)'teki şekilde

$$
\sigma=K . \varepsilon_{p}{ }^{n}
$$

Burada $\mathrm{K}$, mukavemet katsayısını ve $\mathrm{n}$, pekleşme üstelini temsil etmektedir. Bu modellerden farklı olarak malzeme davranışını anizotropik olarak kabul eden, izotropik pekleşme temelli ve en sık kullanılan malzeme modelleri Barlat-89 ve Hill-48 modelleridir. Barlat-89 modeli akma yüzeyi malzemenin anizotropik parametrelerine bağlı olarak elde etmektedir. Düzlem gerilme problemleri için model şu şekilde yazılabilir.

$$
2 \sigma_{y}^{m}=a\left|K_{1}+K_{2}\right|^{m}+a\left|K_{1}-K_{2}\right|^{m}+c\left|K_{2}\right|^{m}
$$

Burada $\sigma_{\mathrm{y}}$ akma gerilmesi olup $\mathrm{K}_{1}$ ve $\mathrm{K}_{2}$ farklı yönlerdeki akma gerilmelerine, a ve c ise anizotropi katsayılarına bağlı parametrelerdir. Yine bu denklemde yer alan $\mathrm{m}$ üsteli ise malzemenin kristal kafes yapısı ile ilişkili olup yüzey merkezli kübik malzemeler için 8, hacim merkezli kübik malzemeler için ise 6 olarak kullanılması tavsiye edilmektedir [31]. Barlat dışında malzemeyi anizotropik olarak kabul eden ve günümüzde hala en sık kullanılan plastisite modeli Hill-48'dir. Bu model, düzlem gerilme için şu şekilde yazılabilmektedir.

$$
2 f\left(\sigma_{i j}\right)=(G+H) \sigma_{11}^{2}-2 H \sigma_{11} \sigma_{22}+(H+F) \sigma_{22}^{2}+2 N \sigma_{12}^{2}=1
$$

burada $\sigma_{11}, \sigma_{22}$ asal gerilmeleri ve $\sigma_{12}$ ise kayma akma gerilmeleridir. F, G H ve $\mathrm{N}$ sabitleri ise malzemenin anizotropi katsayılarına ve/veya akma gerilmelerine bağlı parametrelerdir.

Çalışmada incelenilen üçüncü grup plastisite modelli olarak ise kinematik pekleşme kabulü yapan modellerden günümüzde en sık kullanılan Yoshida-Uemori [32] kinematik pekleşme modeli tercih edilmiştir. Pekleşmeyi temsil edebilmek adına bu model, akma yüzeyi ve sınır yüzey olmak üzere iki yüzeye ihtiyaç duymaktadır. Şekillendirme prosesinde, akma yüzeyi boyut olarak değişmez fakat deformasyonla akma yüzeyinin merkez noktası hareket eder, sınır yüzeyi ise hem şekil olarak hem de konum olarak değişir. Şekil 1'de iki yüzeyli kinematik modelin şematik gösterimi görülmektedir. Burada, “O” akma yüzeyinin merkez noktasıdır, $\alpha$ *, akma yüzeyinin mevcut durumdaki merkezidir ve $\alpha$ ise sınır yüzeyin merkezidir. $\beta$, iki yüzeyin merkez nokraları arasındaki ilişkiyi temsil etmektedir. Y, akma yüzeyinin boyutudur ve deformasyon süresince değişmemektedir. $B+R$, sınır yüzeyinin boyutunu temsil etmektedir, R izotropik pekleşme ile ilişkilidir. Yoshida nonlineer pekleşme modeli Bauschinger etkisini ve sac metal şekillendirme proseslerindeki malzeme davranışını tanımlamakta başarılı bir modeldir. Yeni nesil yüksek mukavemetli çelikler için de başarılı sonuçlar verebilmektedir. Şekil 4'te Yoshida kinematik pekleşme modeli ile tahmin edilen bir malzeme davranışı gerilme-gerinim eğrisi üzerinde gösterilmiştir.

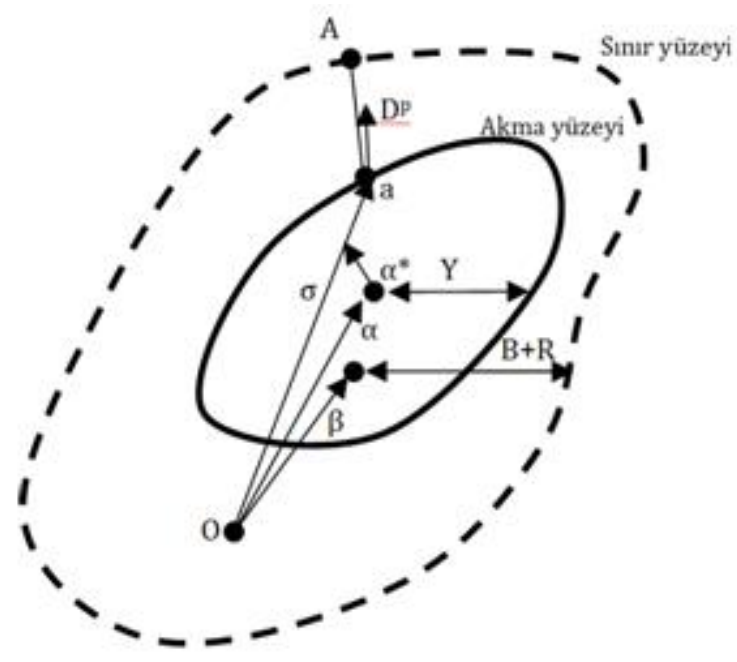

Şekil 4. İki Yüzeyli Modelin Şematik Gösterimi [32]

Yapılan çalışmada yukarıda anlatılan tüm hesaplama parametrelerinin simülasyon hassasiyeti ve simülasyon süresine etkileri ayrı ayrı değerlendirilerek, her bir parametre için en uygun değerler belirlenmiş ve simülasyon süreleri minimize edilmiştir.

\section{Uygulama Çalışması}

Yapılan çalışmada sac metal şekillendirme sonlu elemanlar analizlerinin simülasyon sürelerinin analizi aşamasında uygulama olarak malzemelerin şekillendirilebilirliğinin etkin bir şekilde değerlendirilebildiği kare kutu çekme prosesi kullanılmıştır. Sac metal malzemesi olarak gelişmiş yüksek mukavemetli çelik grubundan TRIP600 çeliği incelenmiştir. Bu çalışma simülasyon süresi ile ilgili 


\section{European Journal of Science and Technology}

olup malzemeden bağımsız bir çalışma olduğundan seçilen malzemenin çalışmanın değerlendirilmesi adımında bir önemi bulunmamaktadır. Kare kutu çekme işlemine ait kalıp takım geometrileri Şekil 5'te verilmiştir. Bu prosesin TRIP600 için deneysel bazda gerçekleştirildiği [33] çalışmasında deneysel sonuç olarak "Şekillendirme kuvveti-Kalıp stroğu" eğrisi verilmiştir. Yapılan simülasyonların hassasiyet açısından doğrulanması bu eğri vasıtası ile yapılmıştır. Deneysel eğri Şekil 6'da görülmektedir. Prosese ait parametreler deney koşulları ile aynı olacak şekilde sonlu elemanlar modellerinin tamamında tanımlanmıştır. Proses parametreleri olarak parça tutucu kuvvet $94 \mathrm{kN}$ ve sürtünme katsayısı 0,125 olarak kullanılmışıtı. Çalışmanın 2. bölümünde anlatılan sonlu elemanlar hesaplama parametreleri kullanılarak kare kutu çekme prosesine ait modelleme işlemleri gerçekleştirilmiştir. Çalışmada hesaplama parametreleri geniş bir küme içerisinde değerlendirilmiş olunup kullanılan parametreler ve bu parametrelere ait değerler Tablo 1'de verilmiştir. Çalışma kapsamında yapılan sonlu elemanlar analizlerinin tamamı Ls-Dyna ticari yazılımında gerçekleştirilmiştir.

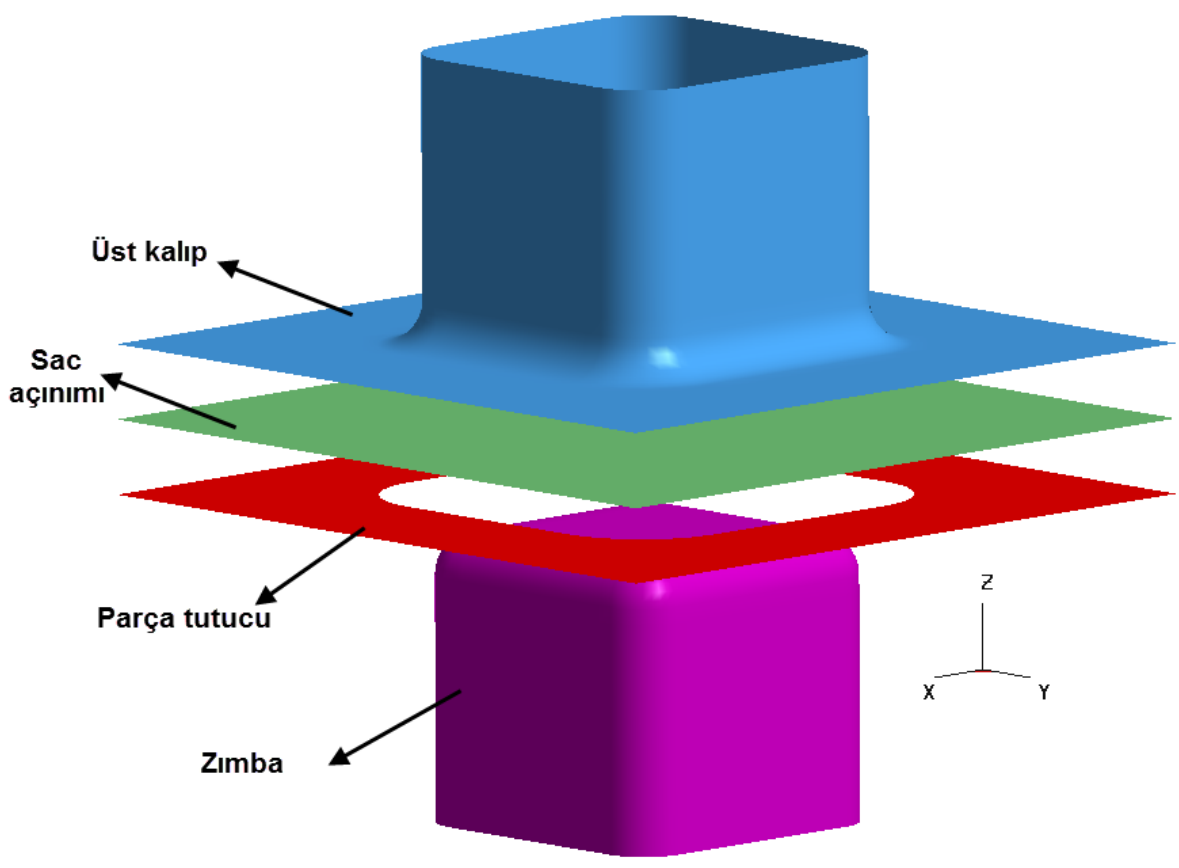

Şekil 5. Kare Kutu Çekme Kalıp Takımı

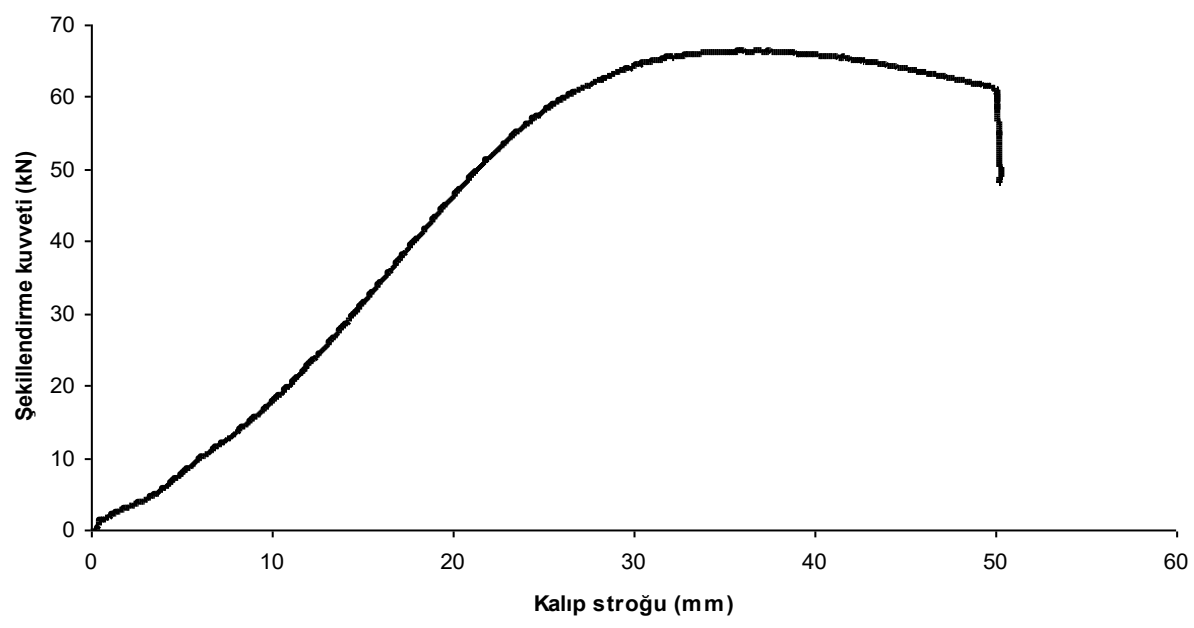

Şekil 6. Deneysel Şekillendirme Kuvveti-Kalıp Stroğu Ĕgrisi 
Avrupa Bilim ve Teknoloji Dergisi

Tablo 1. Çalışmada Kullanılan Sonlu Elemanlar Hesaplama Parametreleri

\begin{tabular}{|c|c|c|c|c|c|c|}
\hline Parametre & \multicolumn{6}{|c|}{ Değer } \\
\hline Simetri Durumu & $1 / 4$ & & $1 / 2$ & & \multicolumn{2}{|c|}{$1 / 1$} \\
\hline Çekirdek Saylsı & \multicolumn{3}{|c|}{4} & \multicolumn{3}{|c|}{8} \\
\hline Adaptiv A ̈̆ Yapısı Derecesi & $\begin{array}{c}0 \\
\text { (Adaptivite yok }\end{array}$ & 1 & 2 & 3 & 4 & 5 \\
\hline Eleman Boyиtи $(\mathrm{mm})$ & 1 & & \multicolumn{2}{|l|}{3} & 5 & 7 \\
\hline İntegrasyon Nokta Saylst & 3 & \multirow{2}{*}{\multicolumn{3}{|c|}{\begin{tabular}{|c|}
5 \\
Belytchsko-Tsay
\end{tabular}}} & 7 & 9 \\
\hline Eleman Formülasyonu & Hughes-Liu & & & & \multicolumn{2}{|c|}{ Fully Integrated } \\
\hline Kalıp Hızı $(\mathrm{mm} / \mathrm{s})$ & \begin{tabular}{l|l}
500 & \\
\end{tabular} & 1000 & & & 3000 & 5000 \\
\hline Zaman Adım Aralığı Ölçeği & \multicolumn{2}{|l|}{$1 / 1$} & \multicolumn{2}{|c|}{$1 / 5$} & \multicolumn{2}{|c|}{$\mathrm{x} 10$} \\
\hline Malzeme Modeli & Power Law & Hill-48 & & & Yosh & Jemori \\
\hline
\end{tabular}

Çalışmada ilk olarak simetri durumu incelenmiş olup kare kutu çekme prosesi eksenel simetriye sahip olduğundan modelleme adımları tam model, yarı model ve çeyrek model olmak üzere üç adımda yapılmıştır. Gerçekleştirilen simülasyonlar sonrasında şekillendirme kuvveti-kalıp stroğu eğrileri elde edilmiş ve deneysel sonuçlar ile kıyaslanmıştır. Karşılaştırma sonuçları Şekil 7'de görülmektedir. Simetri koşulları değerlendirildiğinde tahmin performanslarının oldukça benzer oldukları görülmektedir. Sonuç olarak simetri koşulunun simülasyon hassasiyetini efektif bir şekilde etkilemediği tespit edilmiştir. Simülasyon sonuçları karşılaştırıldığında simetri koşulunun etkisi açıkça görülmektedir. Sonlu elemanlar analizi sürelerinin karşılaştırılması Şekil 8'de verilmiştir. Şekilden görüldüğü üzere çeyrek modelli simülasyon oldukça avantajlı olarak öne çıkmaktadır. Bu nedenle modelleme çalışmanın sonraki adımlarında çeyrek model kullanılmıştır.

\section{SIMMETRİ DURUMU}

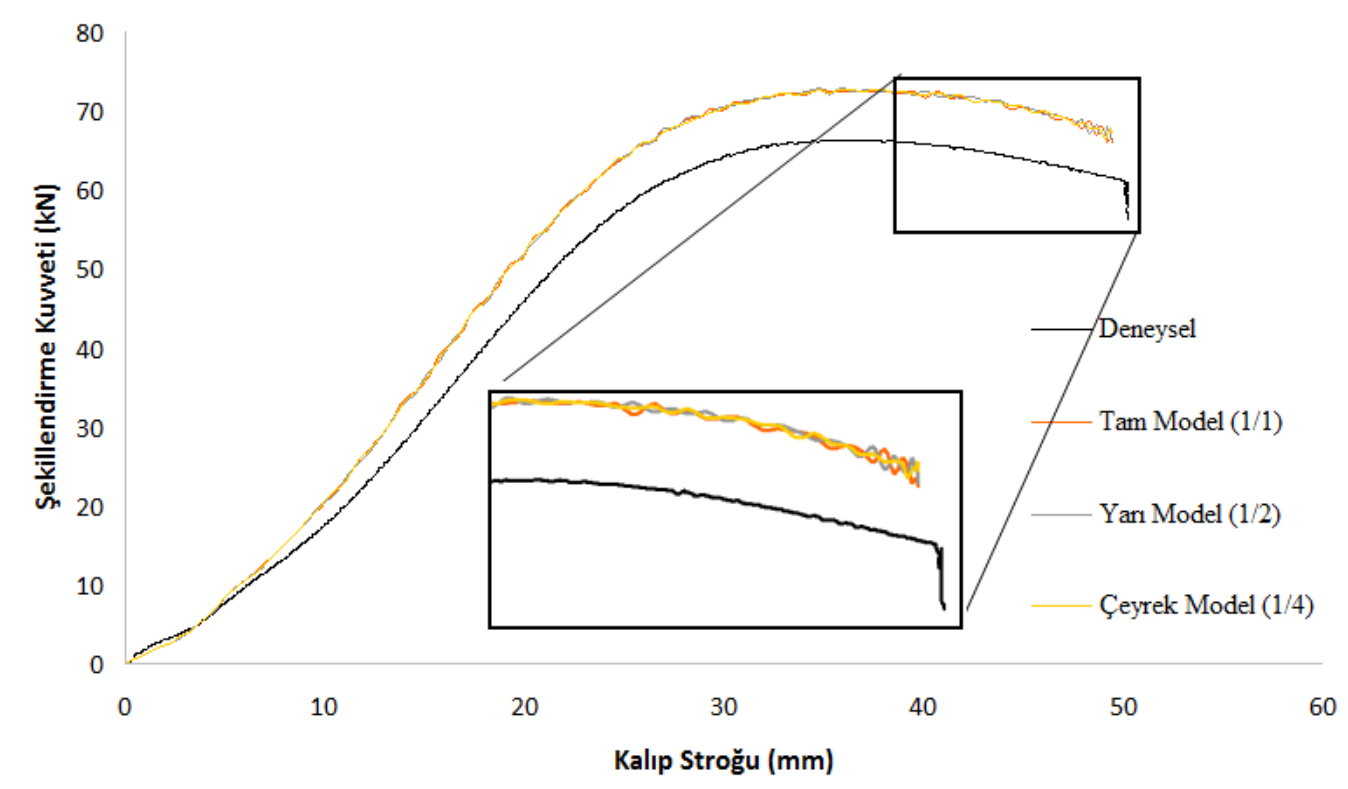

Şekil 7. Simetri durumuna göre kuvvet-strok eğrilerinin karşılaştırllması 


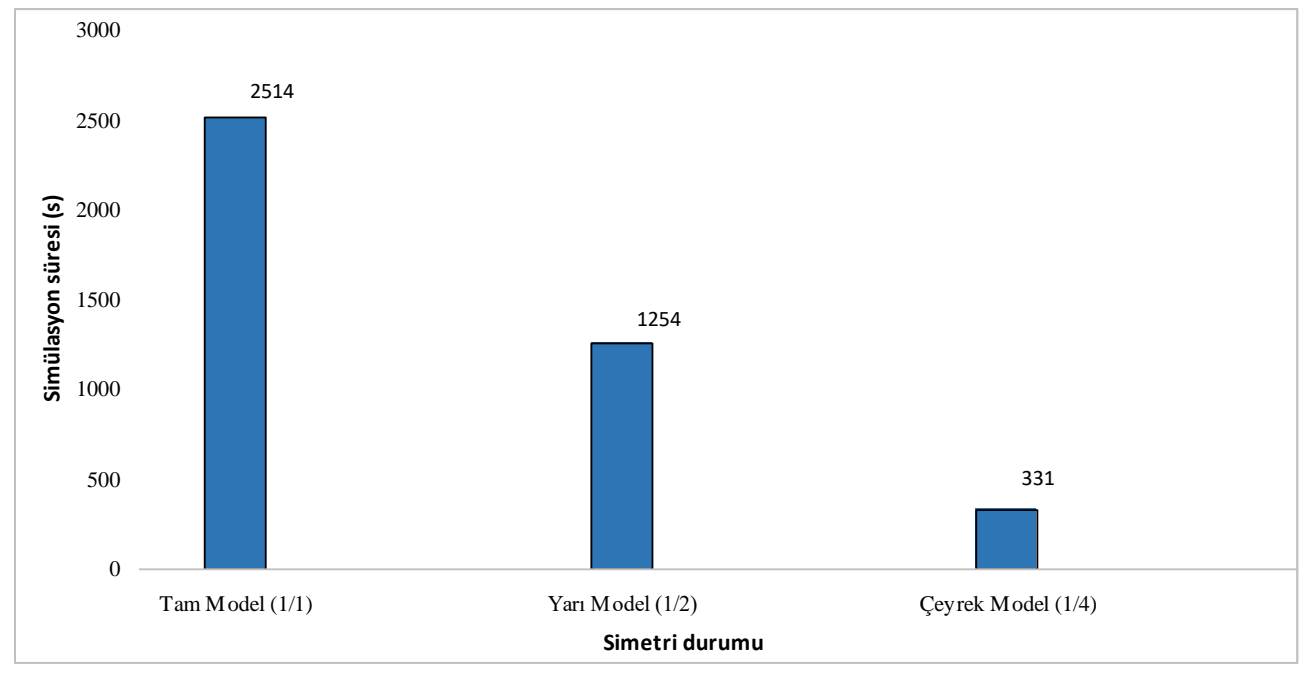

Şekil 8. Simetri durumuna göre simülasyon sürelerinin karşılaştırılması

Çalışmanın ikinci adımında eleman boyutunun etkisi incelenmiştir. Sac açınımına ait eleman boyutları 1, 3, 5 ve 7 mm olarak kullanılmış ve sonlu elemanlar analizleri gerçekleştirilmiştir. Kuvvet-strok eğrilerinin deneysel sonuçla kıyaslanması Şekil 9'da, simülasyon sürelerinin durumu ise Şekil 10 'da görülmektedir. Şekillerden görüldüğü üzere eleman boyutunun büyümesi simülasyon süresini belirgin bir şekilde düşürmektedir fakat hassasiyet açısından bakıldığında eleman boyutunun büyümesi hassasiyeti negatif şekilde etkilemektedir. Tercih önceliği tahmin hassasiyeti olduğundan sonraki simülasyonlar için 1 mm eleman boyutu tercih edilmiştir.

\section{ELEMAN BOYUTU}

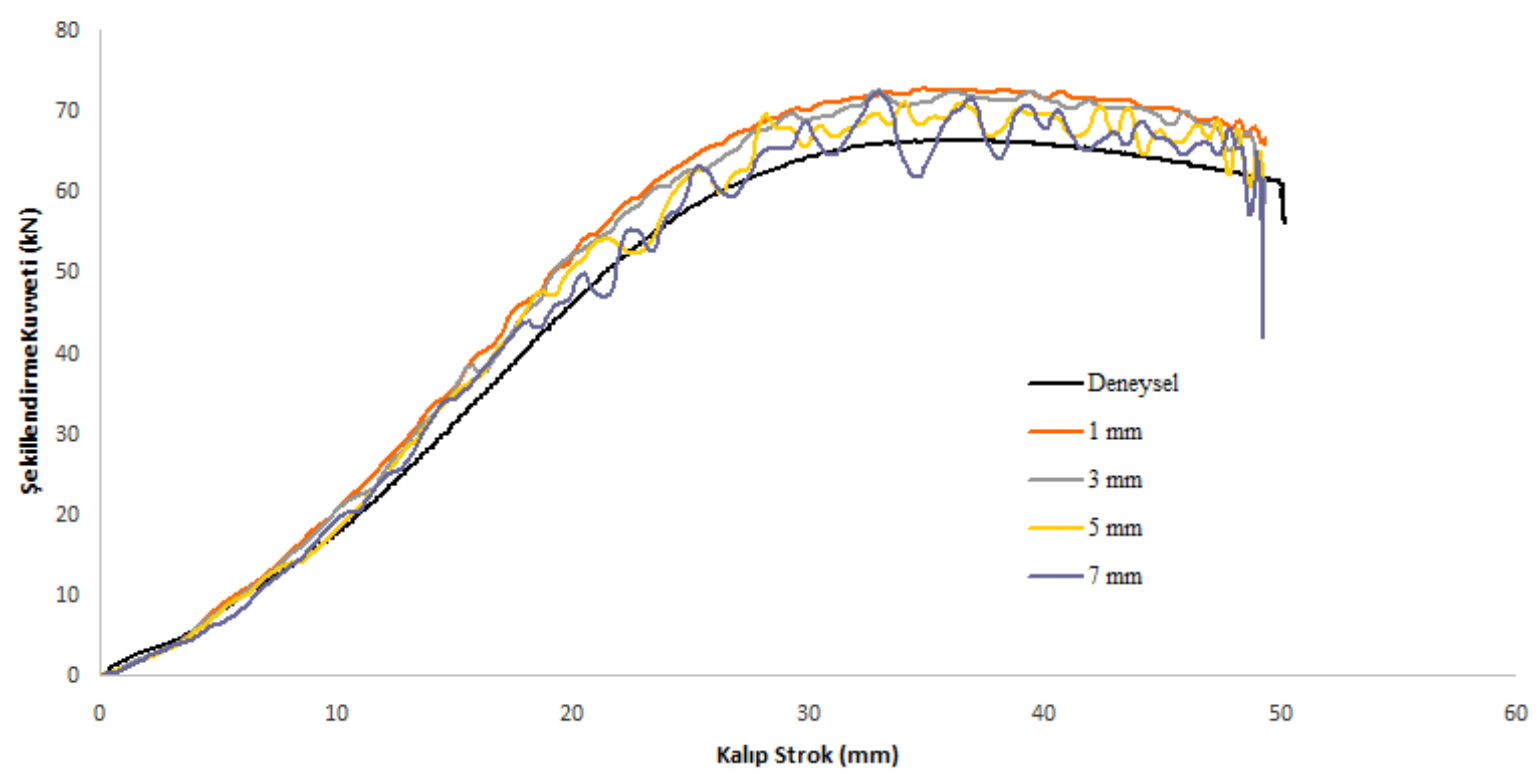

Şekil 9. Eleman boyutuna göre kuvvet-strok eğrilerinin karşılaştırılması 


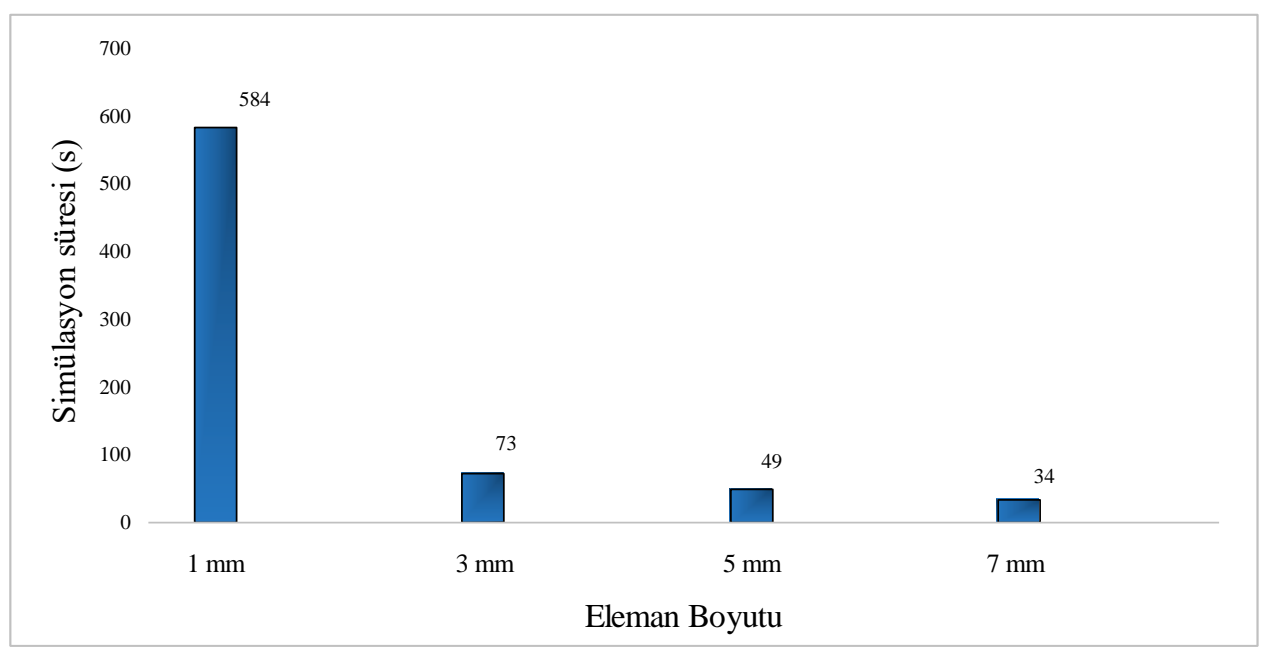

Şekil 10. Eleman boyutuna göre simülasyon sürelerinin karşılaştırılması

Çalışmanın bir diğer adımında deformasyon hızının etkisi incelenmiş olup bu kapsamda kalıp ilerleme hızı hesaplama parametresi olarak kullanılmıştır. Şekillendirme hızı değerleri 500, 1000, 2000, 3000 ve $5000 \mathrm{~mm} / \mathrm{s}$ olarak belirlenmiş ve simülasyonlar gerçekleştirilmiştir. Simülasyonların hassasiyet karşılaştırması Şekil 11'da, sürelerinin karşılaştırması ise Şekil 12'de verilmiştir. Deneysel sonuçlarla kıyaslamalar incelendiğinde $5000 \mathrm{~mm} / \mathrm{s} \mathrm{hız} \mathrm{değerinin} \mathrm{deneysel} \mathrm{eğriden} \mathrm{uzak} \mathrm{tahminde} \mathrm{bulunduğu,}$ diğer hız değerlerinin ise birbirlerine yakın sonuç verdikleri tespit edilmiştir. Süre açısından parametreler incelendiğinde $2000 \mathrm{~mm} / \mathrm{s}$ hız değerinin hem süreden hem de hassasiyet açısından en uygun değer olduğu tespit edilmiştir.

\section{KALIP HIZI}

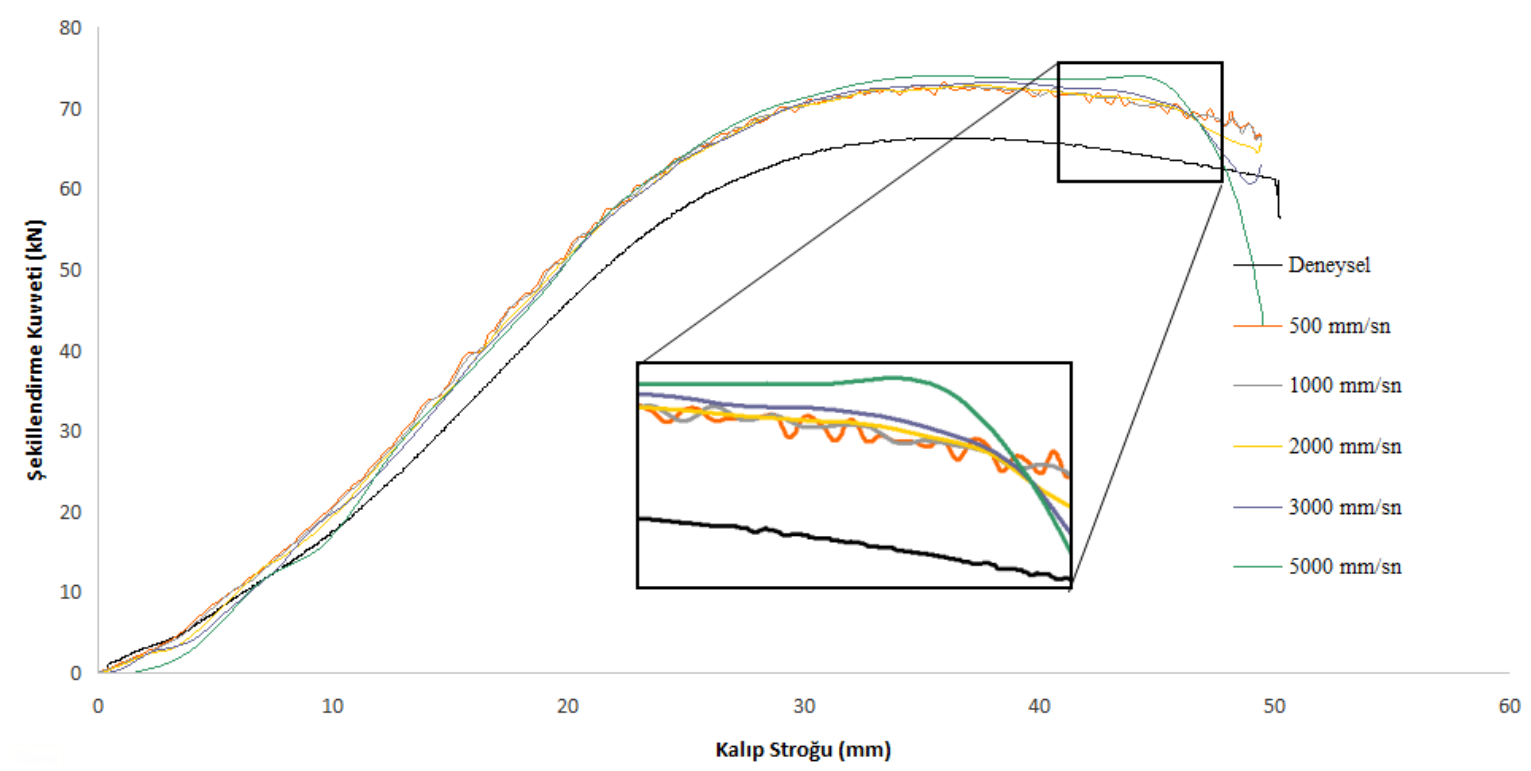

Şekil 11. Kalıp hızına göre kuvvet-strok eğrilerinin karşılaştırılması 


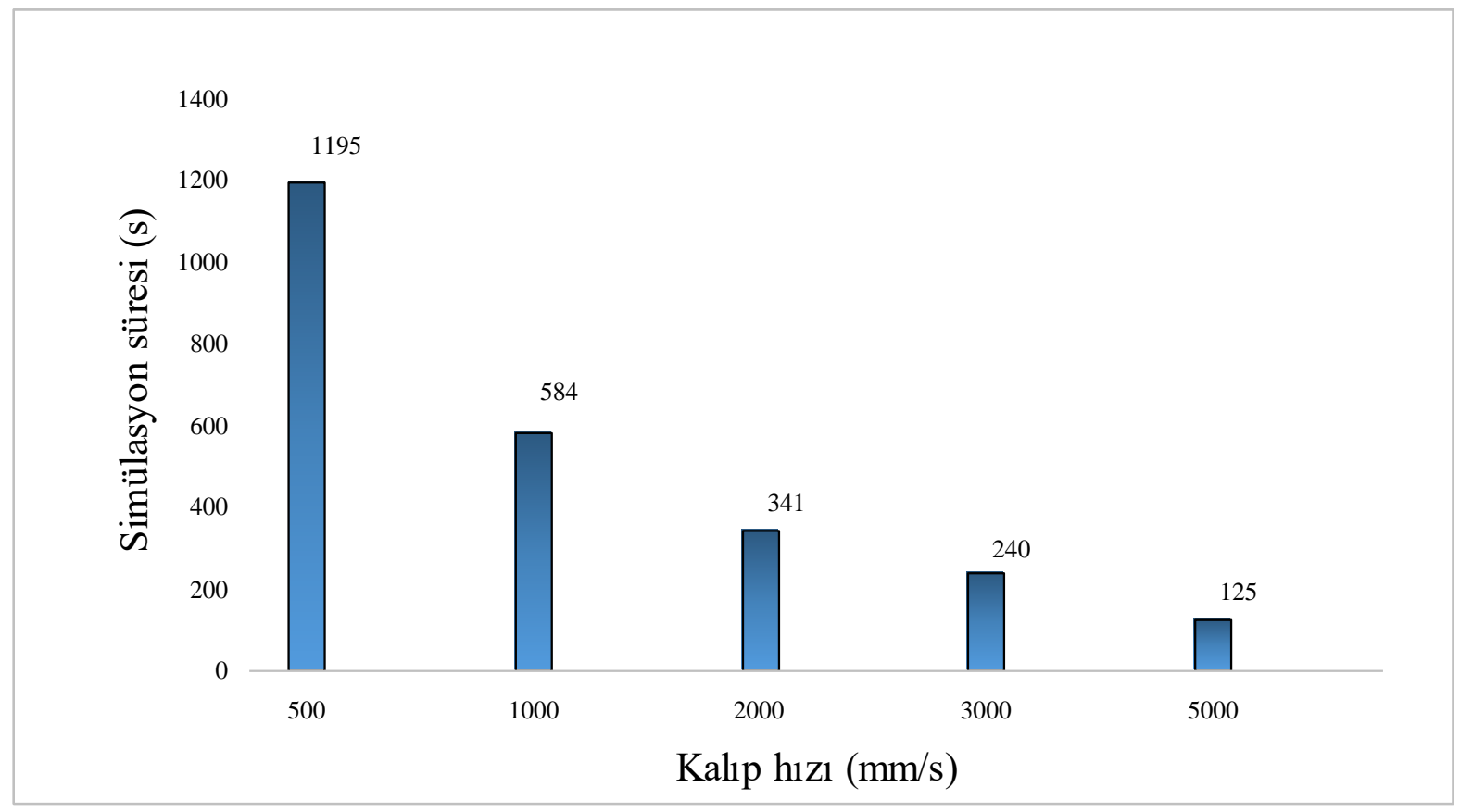

Şekil 14.Kalıp hızına göre simülasyon sürelerinin karşılaştırılması

Çalışmada farklı malzeme modellerinin kullanımı incelemek amacı ile deneysel sonuçla karşılaştırmak adına 4 farklı plastisite modeli çalışılmıştır. Yapılan simülasyonlar sonrasında karşılaştırma sonuçları hassasiyet açısından Şekil 13'te, süre açısından ise Şekil 14'te verilmiştir. Barlat-89 modelinin gerçekten oldukça uzak bir sonuç verdiği görülmektedir. Bu durum Barlat-89 modelinin yeni nesil çelikler için çok uygun olmadığını göstermektedir. Diğer malzeme modelleri ile yapılan karşılaştırma sonucunda hem hassasiyet hem de süre açısından Hill-48 malzeme modelinin en uygun plastisite modeli olduğu tespit edilmiştir.

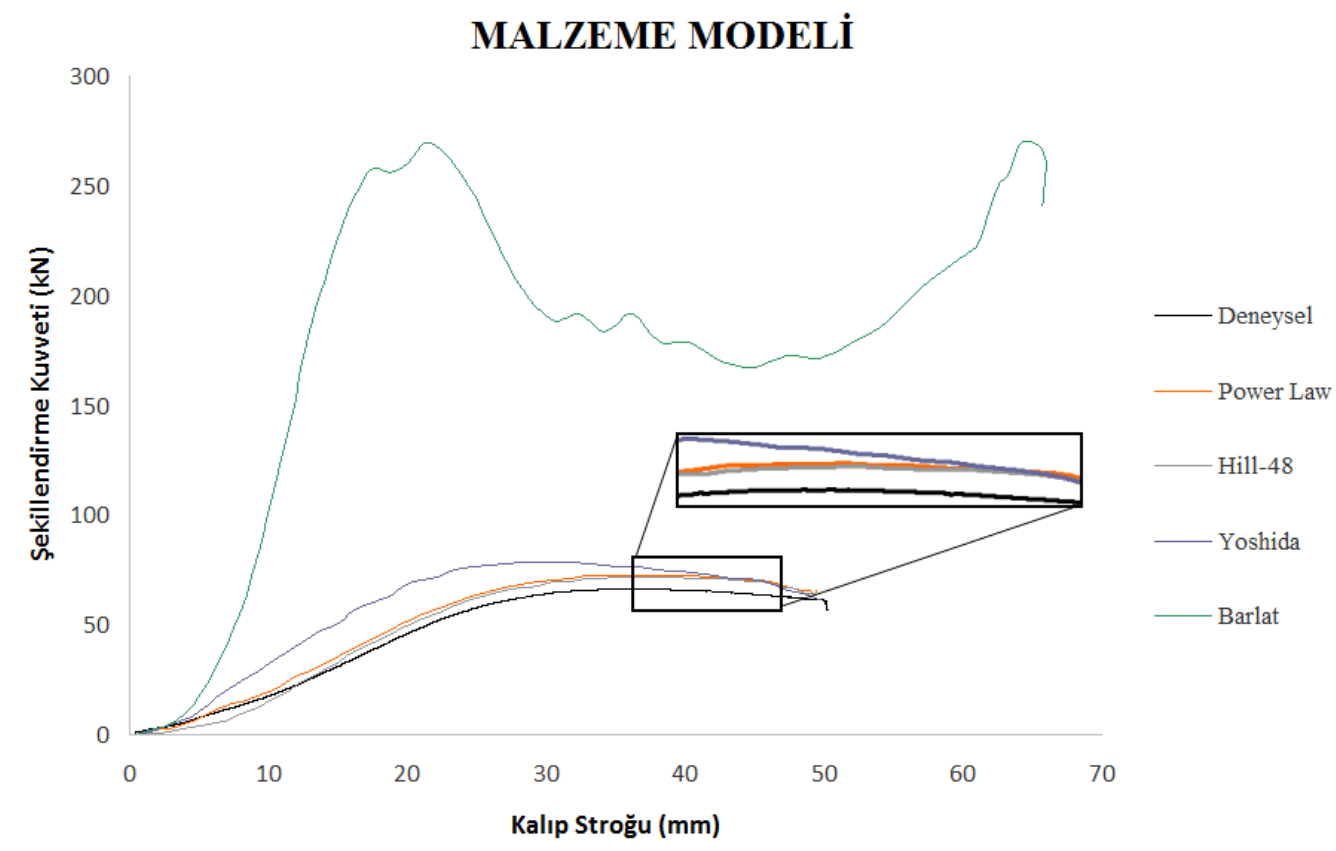

Şekil 13. Malzeme modeline göre kuvvet-strok eğrilerinin karşılaştırllması 


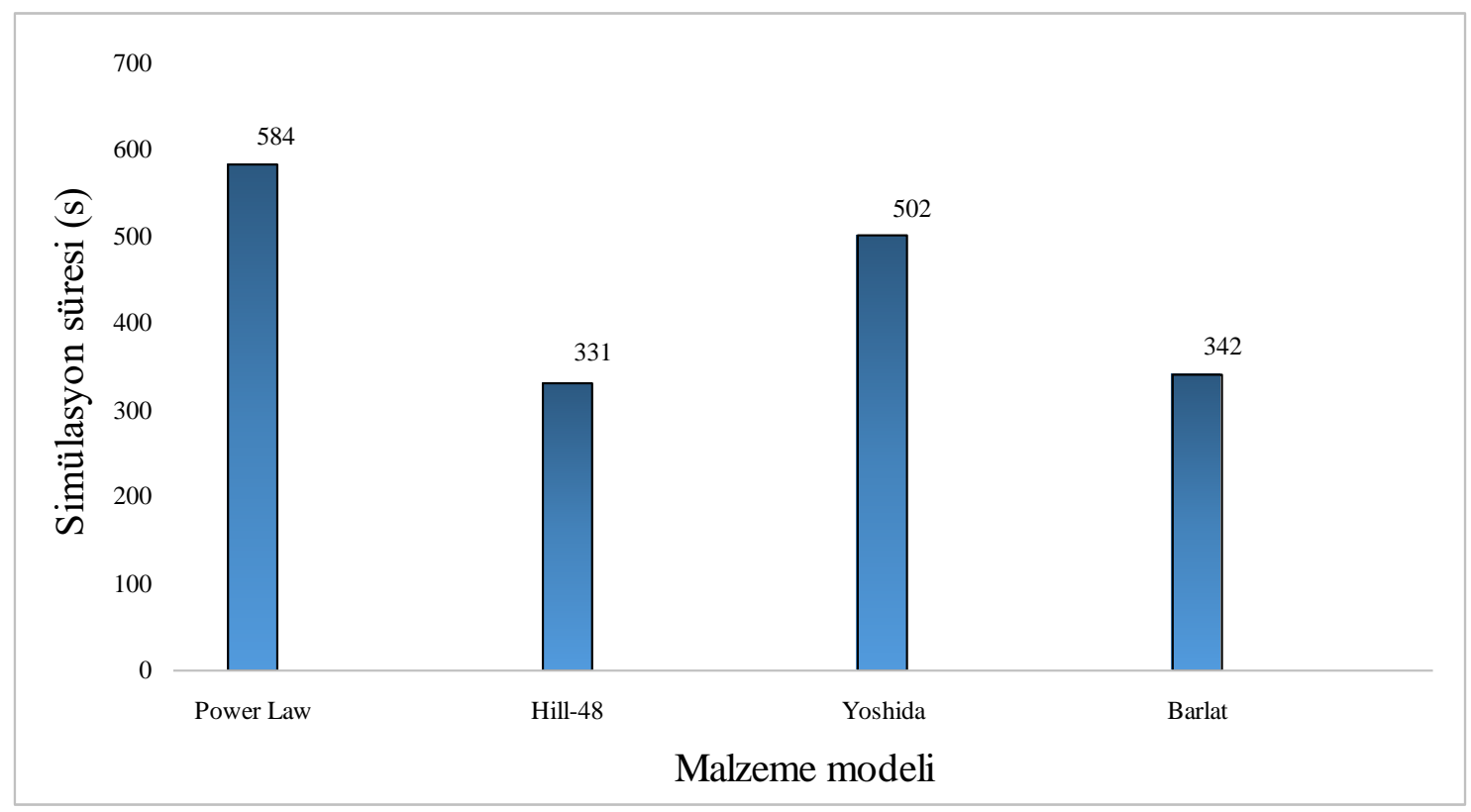

Şekil 14.Malzeme modeline göre simülasyon sürelerinin karşılaştırılması

Çalışmanın sonraki adımında ağ yapısı adaptivitesi incelenmiştir. Bu kapsamda ilk olarak ağ adaptasyonu kullanılmadan sac açınımının başlangıç ağ yapısı korunarak simülasyon gerçekleştirilmiştir. Diğer durumlarda ise ağ adaptasyon seviyesi 1, 2, 3, 4 ve 5 olarak kullanılmıştır. Hassasiyet açısından sonuçların değerlendirilmesi Şekil 15 'te verilmiştir. Görüldüğü üzere ağ adaptasyonunda da etkin bir hassasiyet değişimi tespit edilmemiştir. Bu durumda simülasyon süreleri karşılaştırılmıştır (Şekil 16). En kısa sürede çözüme ulaşan durum ağ adaptasyonunun bulunmadığı durum olarak tespit edilmiş̧ir. Bu nedenle, çalışmanın sonraki simülasyonlarında ağ adaptasyonu kullanılmamıştır.

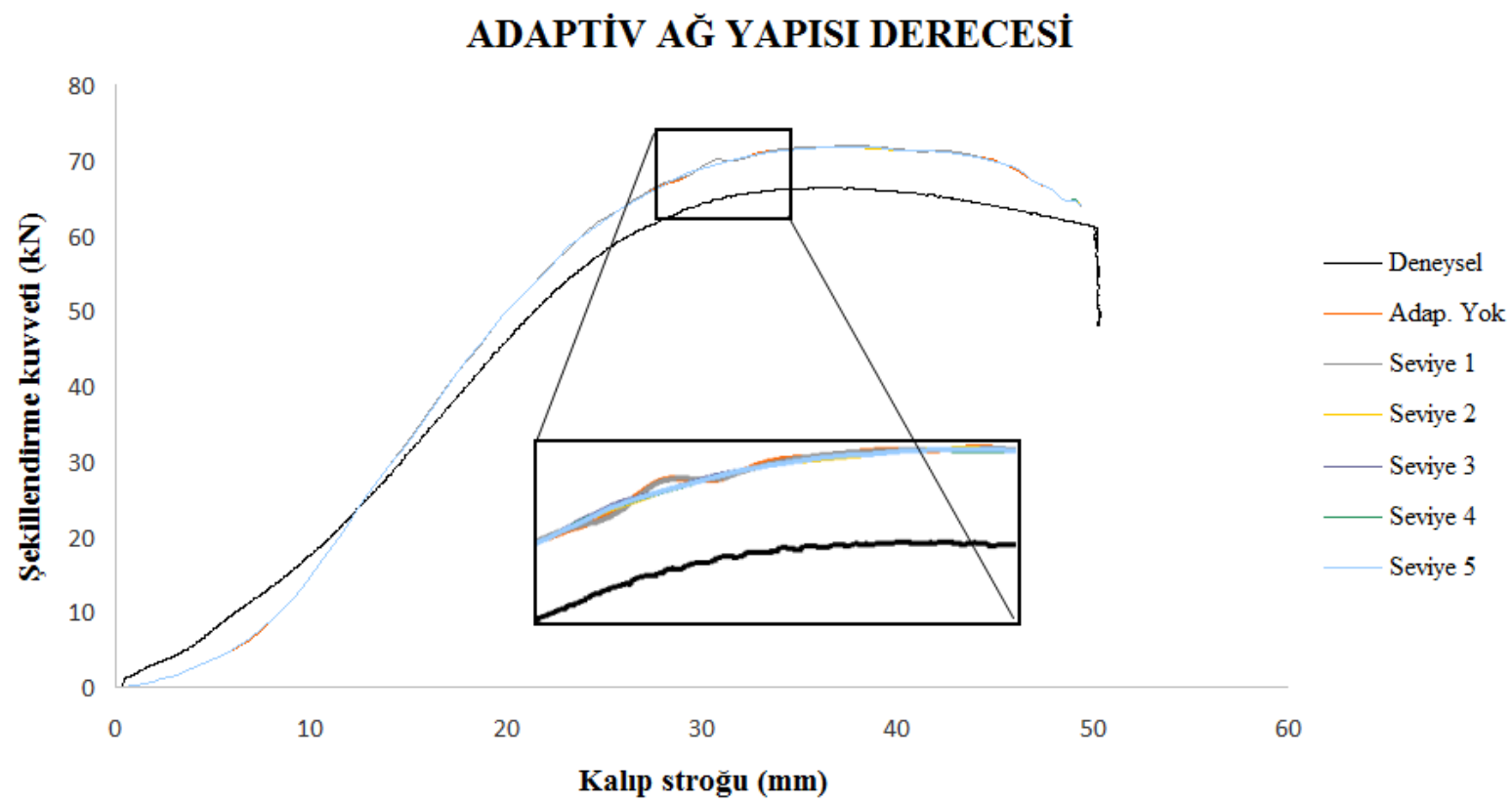

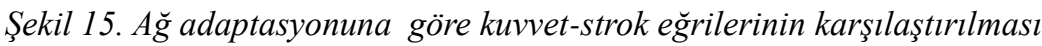




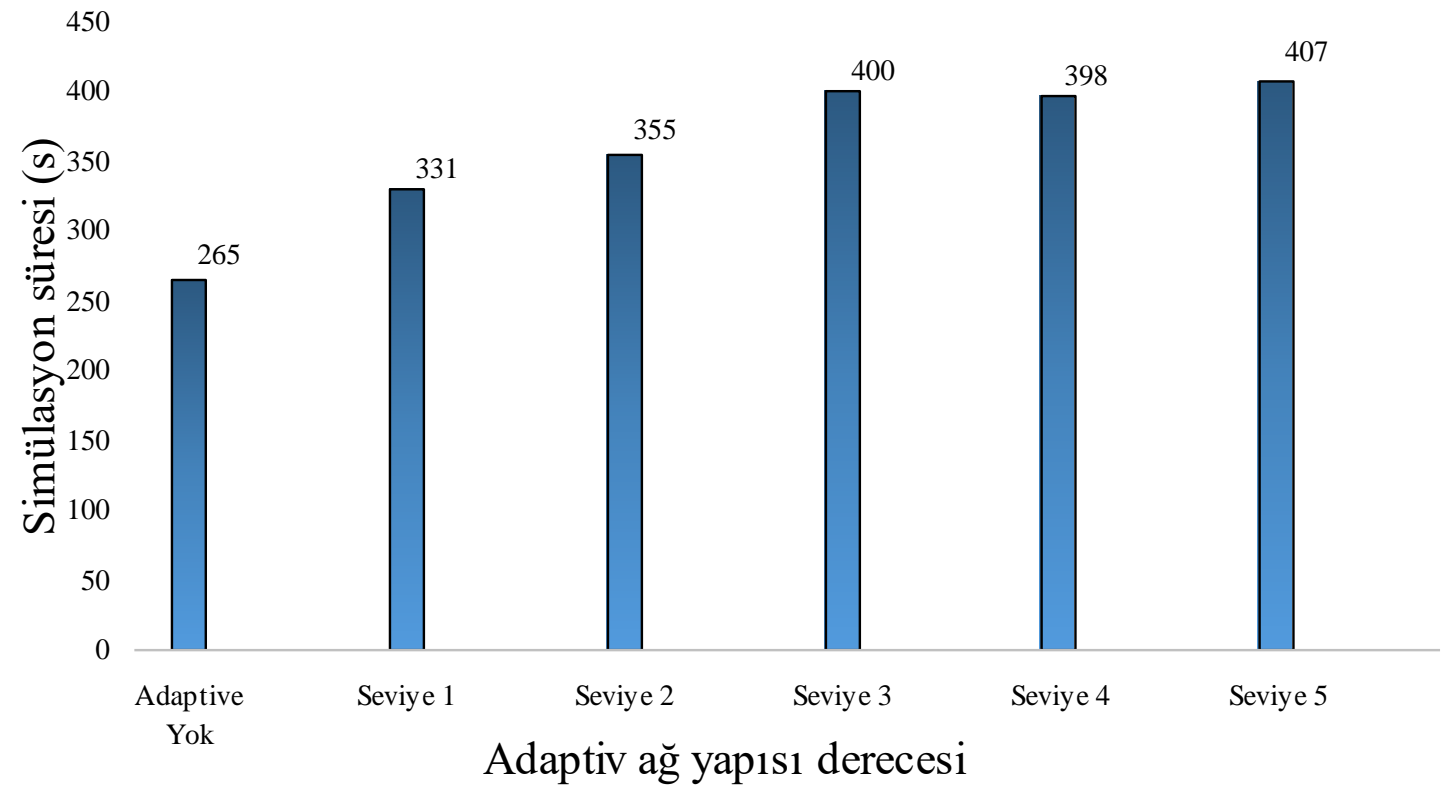

Şekil 16.A ğ adaptasyonuna göre simülasyon sürelerinin karşılaştırılması

Bir diğer parametre olarak eleman formülasyonunun etkisi incelenmiştir. Elaman formülasyonu olarak Hughes-Liu, BelytschkoTsay ve Tam integrasyonlu kabuk elemanlar kullanılmıştır. Simülasyonların gerçekleştirilmesi sonucunda elde edilen kuvvet-strok eğrilerinin deneysel sonuçla kıyaslanması Şekil 17'de görülmektedir. Şekilden de görüldüğ̈̈ üzere eleman formülasyonunun tahmin hassasiyetine belirgin bir etkisi tespit edilmemiştir. Simülasyon süreleri karşılaştırıldığında, simülasyon sürelerinin durumu ise Şekil 18 'de görülmektedir. En kısada çözümün gerçekleştirildiği parametre olarak Belytschko-Tsay tespit edilmiş olup, sonraki simülasyonlar bu formülasyon kullanılarak gerçekleştirilmiştir.

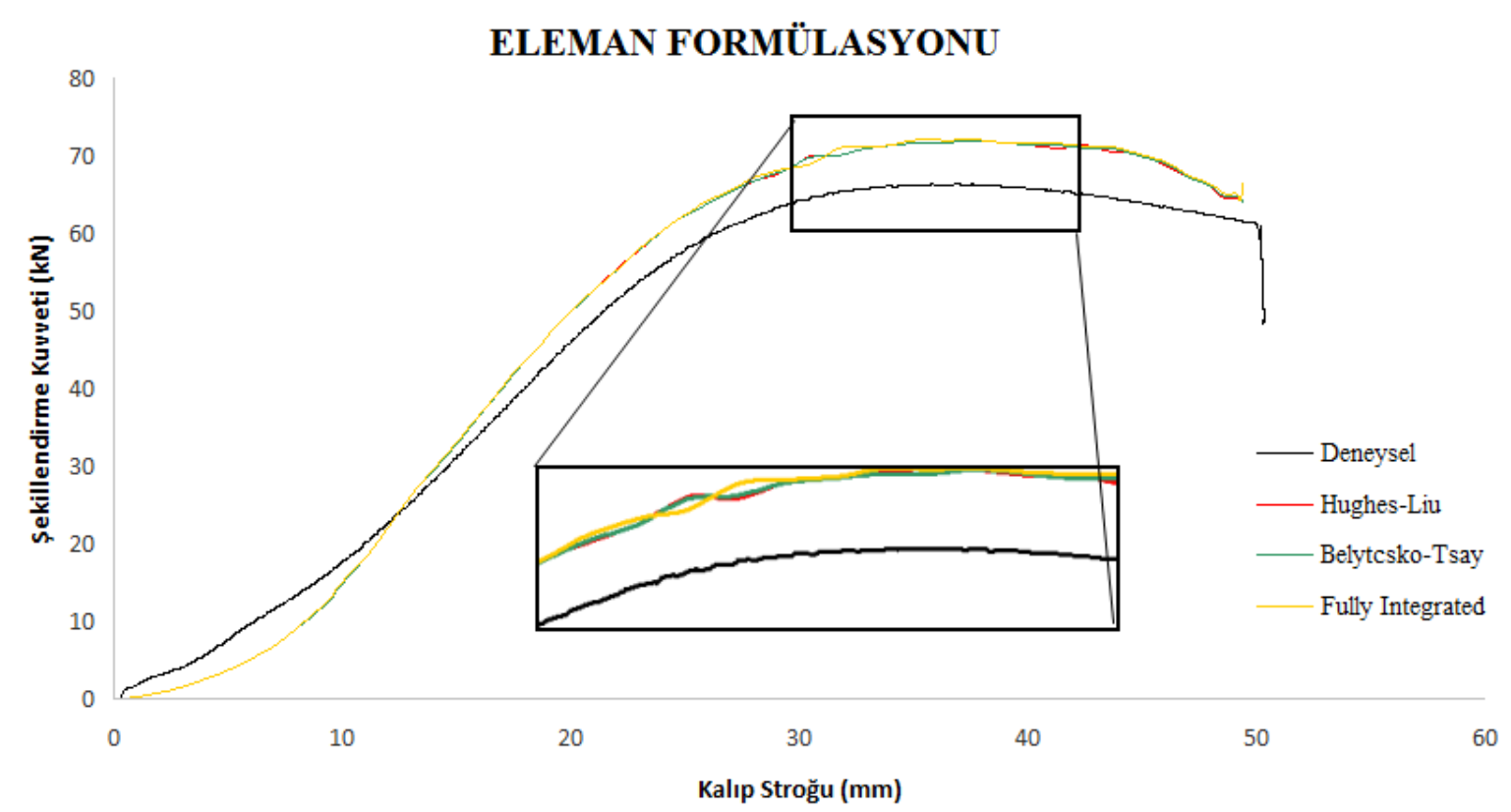

Şekil 17. Eleman formülasyonuna göre kuvvet-strok eğrilerinin karşılaştırılması 


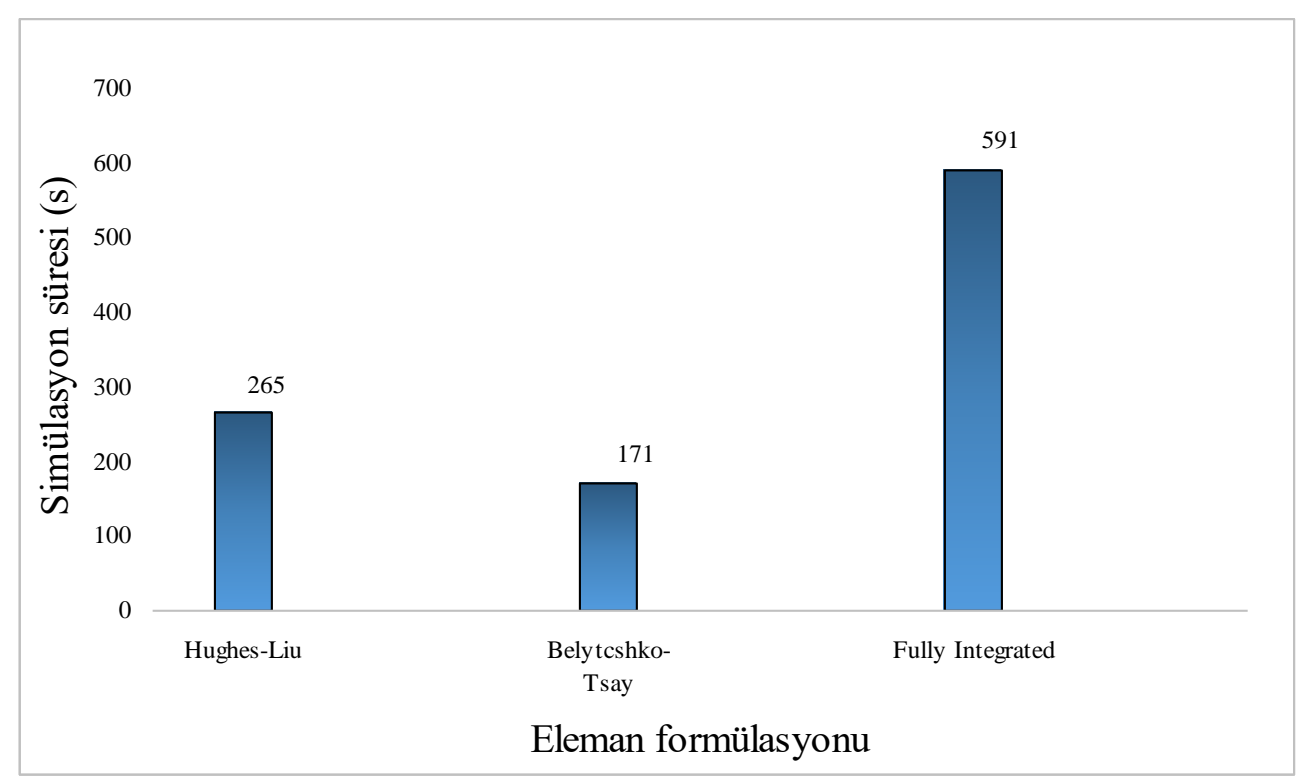

Şekil 18. Eleman formülasyonuna göre simülasyon sürelerinin karşılaştırılması

Çalışmanın bir sonraki adımında hesaplama parametresi olarak integrasyon nokta sayısı incelenmiş olup bu kapsamda kalınlık yönünde 3, 5, 7 ve 9 adet integrasyon noktası kullanılarak simülasyonlar gerçekleştirilmiştir. Elde edilen sonuçların deneysel sonuçla doğrulanması Şekil 19'da verilmiştir. Şekilden de görüldüğü üzere integrasyon nokta sayısının da hassasiyete belirgin bir etkisi tespit edilmemiş̧ir. Bu nedenle simülasyon süreleri karşılaştırılmıştır ve karşılaştırma sonuçları Şekil 20'de verilmiştir. Görüldüğü üzere simülasyon süresinde iyileştirme sağlayan integrasyon nokta sayısı 3 olarak belirlenmiştir.

\section{INNTEGRASYON NOKTA SAYISI}

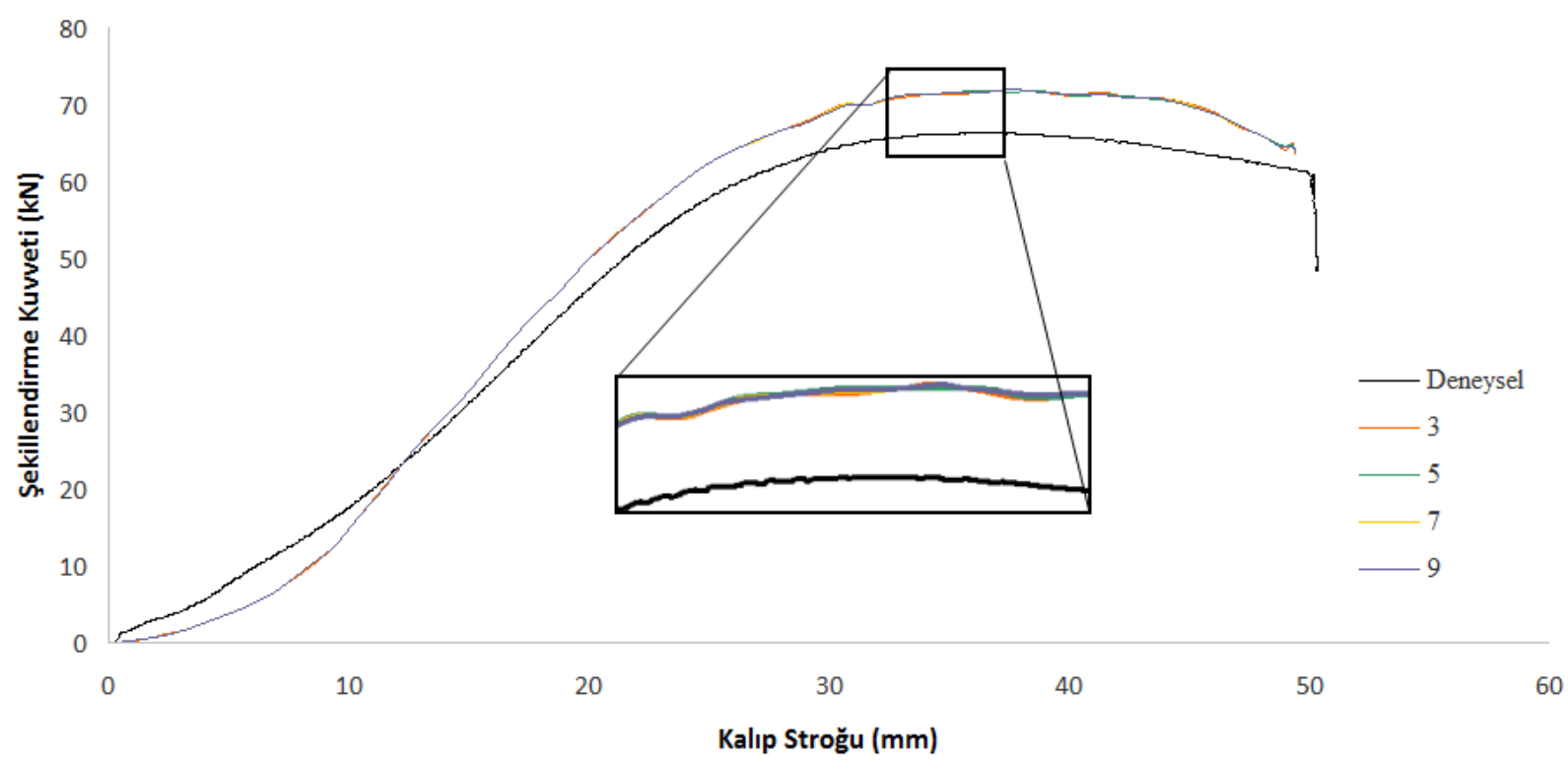

Şekil 19. Integrasyon nokta sayısına göre kuvvet-strok eğrilerinin karşılaş̧trılması 
250

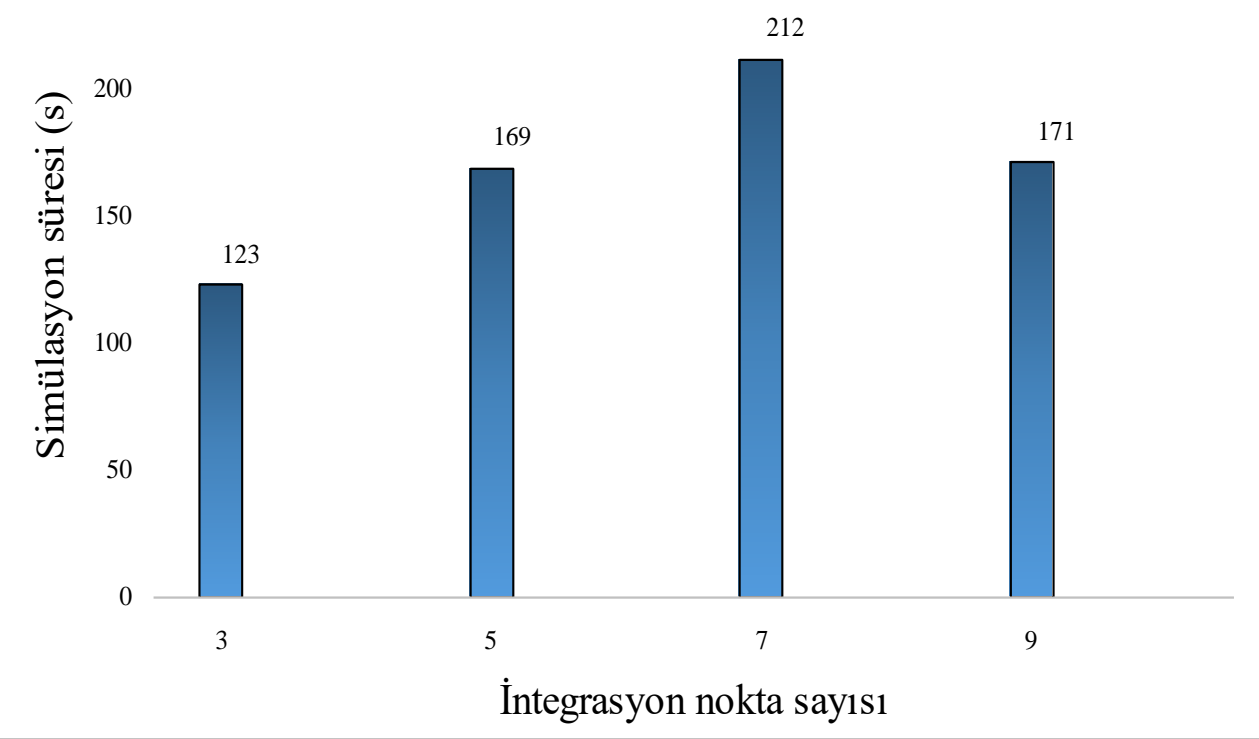

Şekil 20.İntegrasyon nokta sayısına göre simülasyon sürelerinin karşılaşttrılması

Bir sonraki adımda zaman adım aralı̆̆ının etkisi incelenmiştir. Zaman adım aralığı üç farklı parametre değerinde kullanılmıştır. Bunların ilki Denklem (1)'de verildiği şekilde hesaplanan değer (1/1 ölçekli) olarak kullanılan durumdur. Diğer parametreler ise bu değerin 1/5'i ve 10 katı olmak üzere seçilmiştir. Gerçekleştirilen simülasyonlara ait hassasiyet ve sürelere ait sonuçlar sırasıyla Şekil 21 ve Şekil 22'de verilmiştir. Şekillerden görüldüğü üzere zaman adım aralığının yükselmesi hassasiyetten uzak sonuçlar vermektedir. Bunun nedeni zaman adım aralığının büyümesi ile kütle orantısal olarak çözümde artırılmaktadır. Bu nedenle de deneysel sonuçlar yakalanamamaktadır. Hesaplanan değer ve $1 / 5$ ölçeği sonuçlarında ise hassasiyet açısından belirgin bir fark gözlemlenmemiştir. Bu nedenle sürelerin incelenmesi sonucunda zaman adım aralığının hesaplandığı şekilde 1/1 ölçeğinde kullanılmasına karar verilmiştir.

\section{ZAMAN ADIM ARALIĞI}

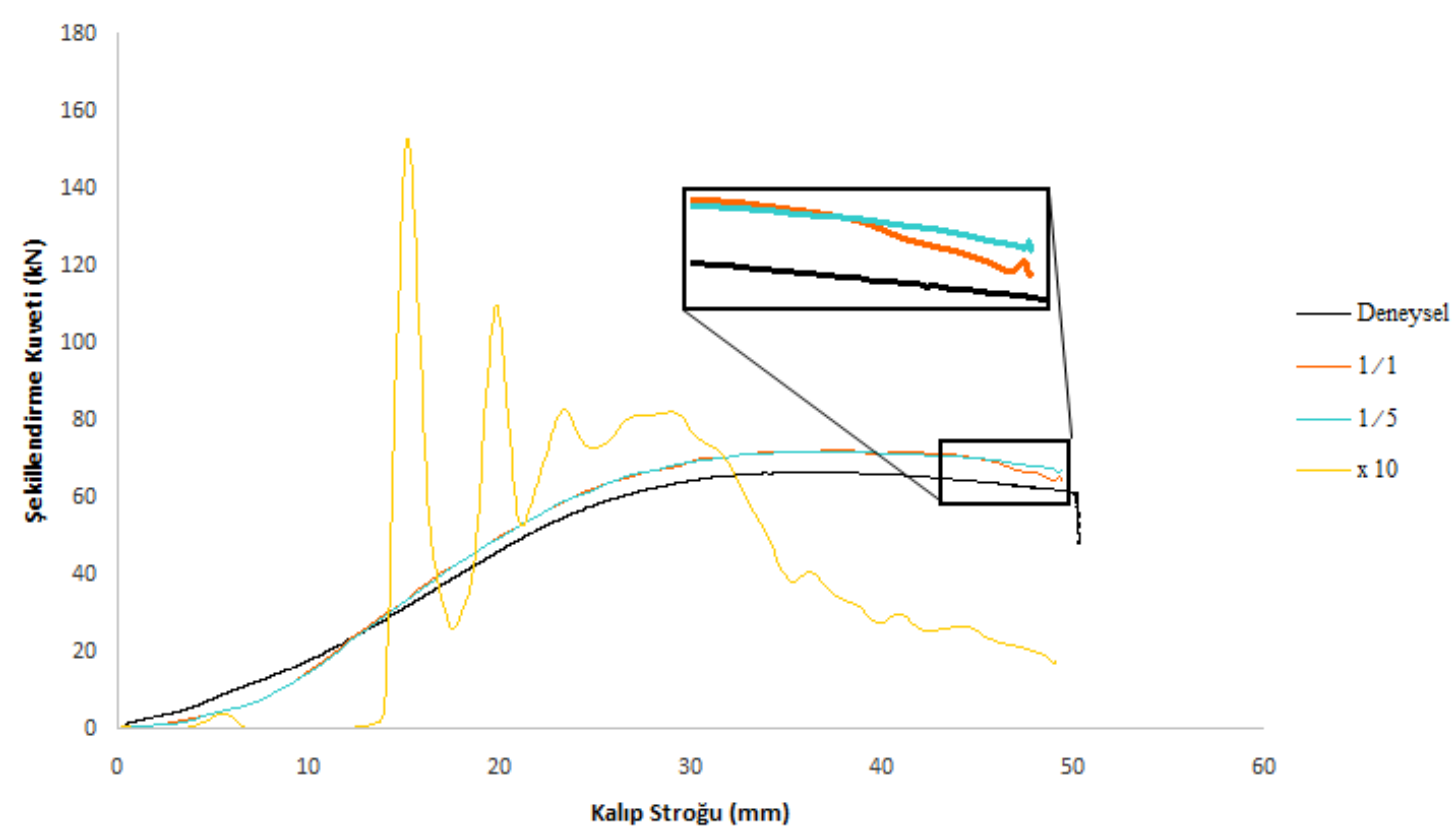

Şekil 21. Zaman adım aralığı ölçeğine göre kuvvet-strok eğrilerinin karşılaştırılması 


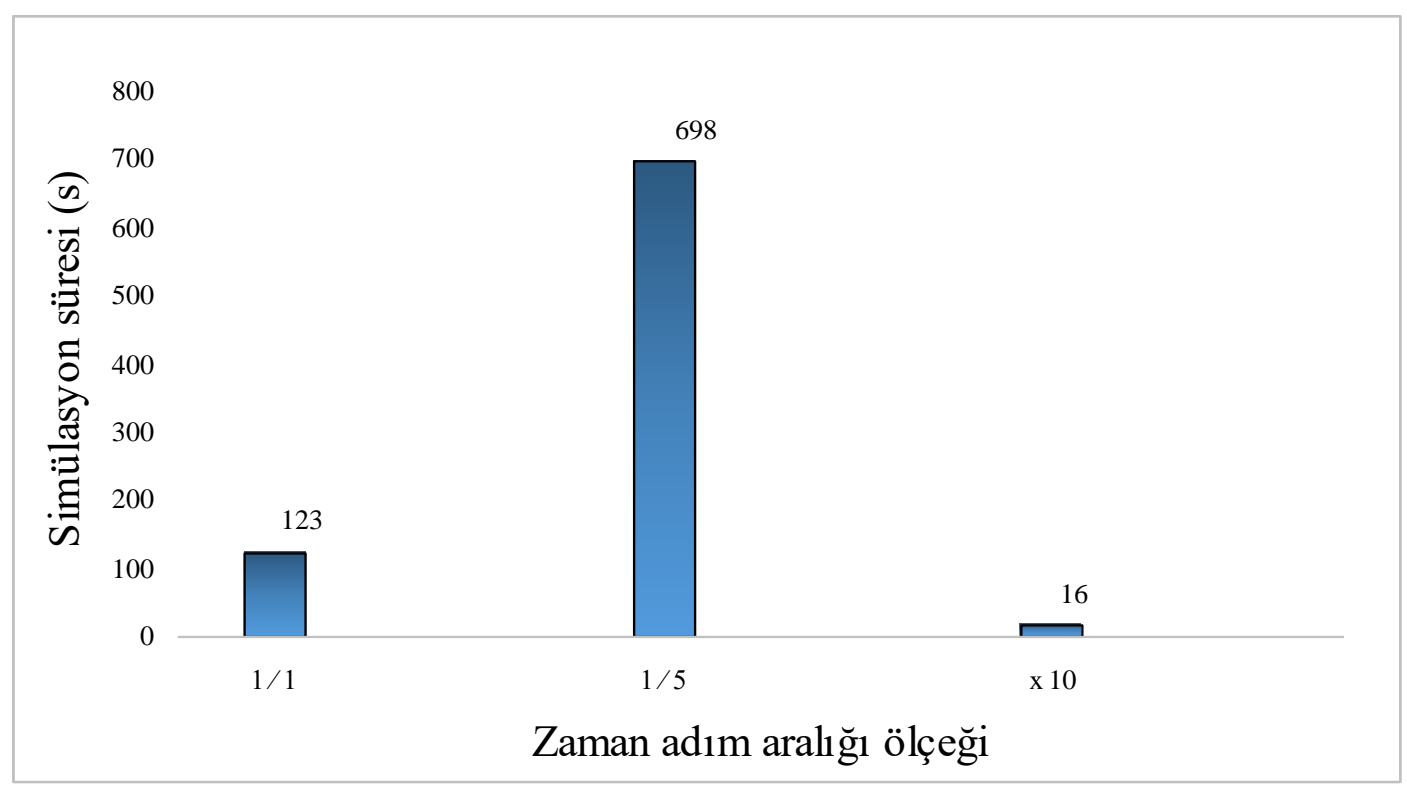

Şekil 22. Zaman adım aralı̆̆ı ölçeğine göre simülasyon sürelerinin karşılaştırılması

Yapılan iyileştirmeler sonrasında simülasyon süresinin 123 saniyeye kadar indirildiği ve hassasiyetin değişmediği görülmektedir. Çalışmada son adım olarak bilgisayar gücünün etkisini irdelemek adına süresi minimize edilmiş simülasyon bir de 8 çekirdekli bir bilgisayarda çözülmüştür. Her iki durum için süre karşılaştırması Şekil 23 'te verilmiştir. Şekilden görüldüğü üzere çekirdek sayısının artması ile birlikte simülasyon süresi 94 saniye seviyesine indirilmiştir.

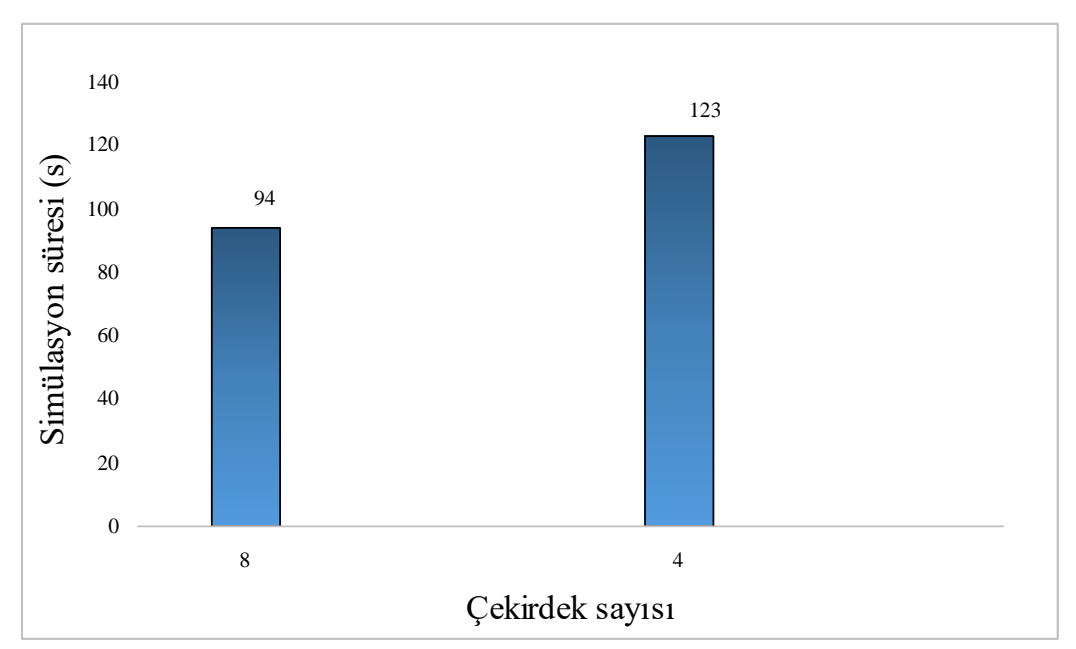

Şekil 23.Bilgisayar çekirdek sayısına göre simülasyon sürelerinin karşılaştırılması

\section{Sonuçlar ve Değerlendirme}

$\mathrm{Bu}$ çalışmada sac metal sonlu elemanlar analizlerinde hassasiyet ve simülasyon süresine hesaplama parametrelerinin etkisi incelenmiştir. $\mathrm{Bu}$ amaç doğrultusunda, sac metal şekillendirme proseslerinden kare kutu çekme prosesi analiz edilmiş olup malzeme olarak gelişmiş yüksek mukavemetli çeliklerden TRIP600 çeliği kullanılmıştır. Kare kutu çekme prosesinde deneysel şekillendirme kuvveti-kalıp stroğu eğrisi referans alınarak hesaplama parametrelerinin tahmin hassasiyeti üzerine etkileri irdelenmiştir. Hassasiyetten ödün vermeden simülasyon süresini kısaltmak amacı ile simülasyon süreleri de inceleme kapsamına alınarak aynı hassasiyette daha kısa sürede çözüm veren parametreler tespit edilmiştir. Sonlu elemanlar hesaplama parametresi olarak, simetri durumu, eleman boyutu, şekillendirme hızı, malzeme modeli, ağ adaptasyon derecesi, eleman formülasyonu, integrasyon nokta sayısı, zaman adım aralığı ve sonlu elemanlar analizlerinin gerçekleştirildiği bilgisayar çekirdek sayısı kullanılmıştır. Her bir hesaplama parametresi için bir değer kümesi belirlenmiş ve her bir değer için simülasyolar gerçekleştirilerek hassasiyet ve süre açısından etkileri incelenmiştir.

İlk parametre olarak kalıp takımının simetri durumu incelendiğinde hassasiyet açısından simetri durumunun bir etkisinin olmadığı tespit edilmiştir. Süre açısından bakıldığında ise en etkin parametrenin simetri durumu olduğu belirlenmiştir. Bu kapsamda tam model, yarı model ve çeyrek model seçeneklerinden en kısa sürede çözüm veren çeyrek model tercih edilmiştir. Eleman boyutu açısından sonuçlar değerlendirildiğinde eleman boyutundaki artışın simülasyon süresini kısalttığı fakat hassasiyete negatif etki ettiği görülmüş̧ür. $\mathrm{Bu}$ nedenle eleman boyutu hassasiyet açısından kritik bulunmuş ve $1 \mathrm{~mm}$ olarak belirlenmiştir. Hesaplama parametrelerinden şekillendirme hızına bakıldığında yüksek hızlarda çözümün süre açısından kısaldığı fakat 5000 mm/s seviyelerinde 
tahmin açısından deneysel sonuçlardan uzaklaşıldığı görülmüştür. Bu nedenle deneysel sonuca en fazla yaklaşan ve en kısa sürede çözüm veren $2000 \mathrm{~mm} / \mathrm{s}$ değeri şekillendirme hızı olarak seçilmiştir. Sonraki adımda malzemenin plastik davranışını tanımlayan malzeme modelleri incelenmiş bu kapsamda da Power Law, Hill-48, Barlat-89 ve Yoshida-Uemori modelleri kullanılmıştır. Bu modellerden Barlat-89 modeli başarılı bir tahmin gerçekleştirememiştir. Barlat-89 modelinin alüminyum malzemeler için daha başarılı tahminler gerçekleştirdiği literatürdeki çalışmalardan bilinmektedir [34]. TRIP600 gibi gelişmiş yüksek mukavemetli çelikler açısından etkin bir tahmin sağlanamamıştır. Yoshida-Uemori modelinde ise deneysel sonucun maksimum kuvvet değerine en yakın tahmin gerçekleştirilse de zamana bağlı değişim açısından deneysel sonuçlarla aynı eğim yakalanamamıştır. Bu nedenle malzeme modeli olarak en hassas ve en kısa sürede sonucun elde edildiği Hill-48 modelinin kullanımı tercih edilmiştir. Bir diğer parametre olarak ağ adaptasyon derecesi incelendiğinde ağ adaptasyon seviyesinin hassasiyet açısından belirgin bir avantajının bulunmadı̆̆ görülmüş olup, süre açısından en optimum yaklaşımı veren durumun ă̆ adaptasyonunun kullanılmadığı durum olduğu tespit edilmiştir. Elemanların hesaplama tekniğini temsil eden eleman formülasyonu ve integrasyon nokta sayıları açısından bir değerlendirme yapıldığında her iki parametredeki değişimin hassasiyete belirgin bir etkisi görülmemiştir. Bu nedenle bu parametrelerden süre açısından avantaj sağlayan değerlerin kullanımı tercih edilmiştir. Bu nedenle eleman formülasyonu olarak Belytschko-Tsay ve integrasyon nokta sayısı olarak 3 seçilmiştir. Bir diğer önemli parametre olarak zaman adım aralığının etkisi irdelenmiştir. Bu kapsamda zaman adım aralığının artmasının simülasyon süresini oldukça kısalttığı görülmüştür. Fakat hassasiyet açısından deneysel sonuçlardan oldukça uzak tahminler gerçekleştirilmiştir. Bunun nedeni zaman adım aralığının artışına paralel olarak sistemde sac metal kütlesinin artırılmasıdır. Son olarak çözümlerin gerçekleştirildiği bilgisayarın çekirdek sayısı incelenmiştir. Bu kapsamda belirlenen parametrelerle 4 çekirdekli ve 8 çekirdekli bilgisayarlarda çözümler gerçekleştirilmiştir. Bu durumda ise yaklaşık \%25 oranında bir süre kazancı sağlanmıştır. Genel tablonun değerlendirilmesinin yapılabilmesi adına başlangıçta gerçekleştirilen simülasyon süresi ile hesaplama parametrelerinin değerlendirilmesi sonrasında elde edilen minimize edilmiş durumun karşılaştırması Şekil 24'te görülmektedir.

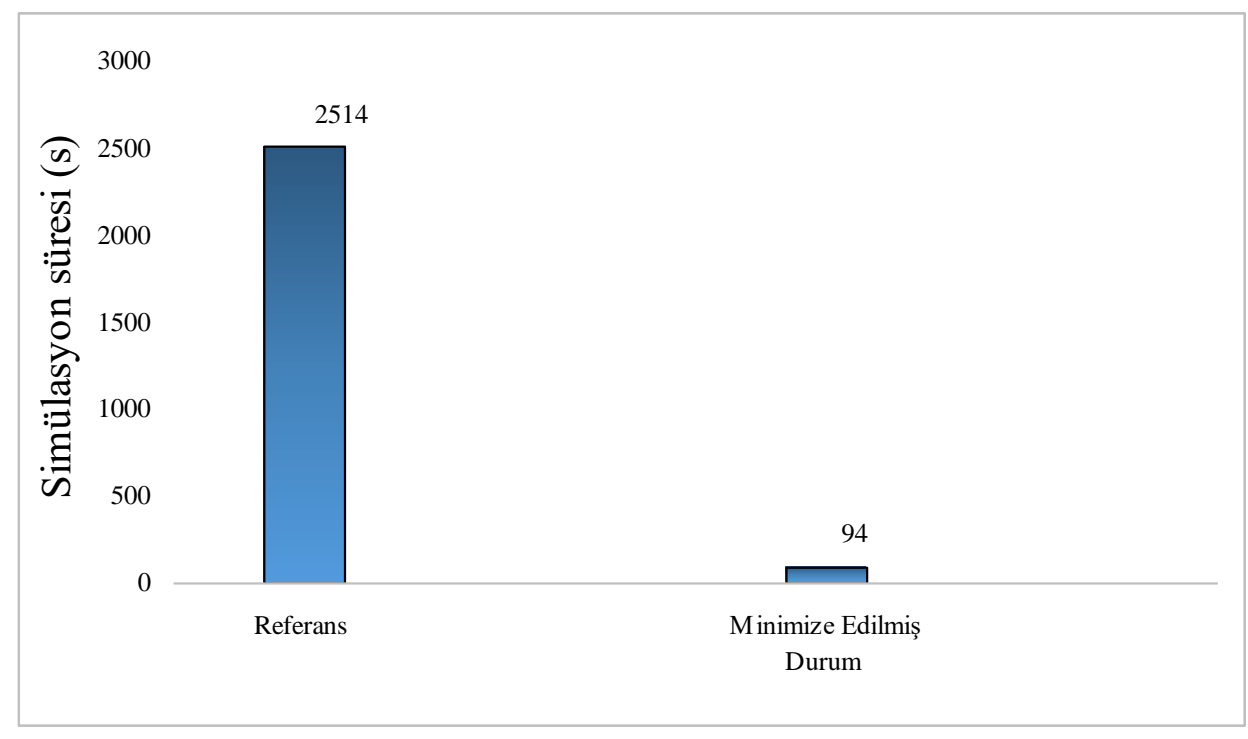

Şekil 24.Başlangıç simülasyonu ve minimize edilmiş durumların simülasyon süresi açısından değerlendirilmesi

Şekilden de görüldüğü üzere hesaplama parametrelerinin simülasyon süresi üzerine belirgin bir etkisi mevcuttur. Bu nedenle doğru parametrelerle çalışılması simülasyon hassasiyetinden ödün vermeden simülasyon süresinin verimli bir şekilde azaltılmasına imkan sağlamaktadır. Özellikle seri imalatın hakim olduğu endüstriler açısından simülasyon sürelerinin verimli kullanılması oldukça önemlidir.

\section{Kaynakça}

[1] Wang, C., Zhang, X., Shen, G., \& Wang, Y. (2019). One-step inverse isogeometric analysis for the simulation of sheet metal forming. Computer Methods in Applied Mechanics and Engineering.

[2] Candra, S., Batan, I. M. L., Berata, W., \& Pramono, A. S. (2015). Analytical study and FEM simulation of the maximum varying blank holder force to prevent cracking on cylindrical cup deep drawing. Procedia Cirp, 26, 548-553.

[3] Qin, S. J., Xiong, B. Q., Hong, L. U., \& Zhang, T. T. (2012). Critical blank-holder force in axisymmetric deep drawing. Transactions of Nonferrous Metals Society of China, 22, s239-s246.

[4] Baffari, D., Buffa, G., Ingarao, G., Masnata, A., \& Fratini, L. (2019). Aluminium sheet metal scrap recycling through friction consolidation. Procedia Manufacturing, 29, 560-566.

[5] Seshacharyulu, K., Bandhavi, C., Naik, B. B., Rao, S. S., \& Singh, S. K. (2018). Understanding Friction in sheet metal forming-A review. Materials Today: Proceedings, 5(9), 18238-18244.

[6] Zhang, Q. F., Cai, Z. Y., Zhang, Y., \& Li, M. Z. (2013). Springback compensation method for doubly curved plate in multi-point forming. Materials \& Design, 47, 377-385.

[7] Dahale, P. S., Pawar, P. D., \& Patil, V. G. (2018). Assessment of Boundary Conditions for FEA of Mounting Bracket Using Corelation with Experimental Results. Materials Today: Proceedings, 5(5), 13290-13300. 
[8] He, B., Yang, W., \& Liu, F. (2019). The material parameter design and finite element simulation of the quadrilateral thermal cloak device. Applied Mathematics Letters, 94, 99-104.

[9] Chen, K., Ma, H., Che, L., Li, Z., \& Wen, B. (2019). Comparison of meshing characteristics of helical gears with spalling fault using analytical and finite-element methods. Mechanical Systems and Signal Processing, 121, 279-298.

[10] Macneal, R. H., \& Harder, R. L. (1985). A proposed standard set of problems to test finite element accuracy. Finite elements in analysis and design, 1(1), 3-20.

[11] Ewing, R. E., Lin, T., \& Lin, Y. (2002). On the accuracy of the finite volume element method based on piecewise linear polynomials. SIAM Journal on Numerical Analysis, 39(6), 1865-1888.

[12] Dawson, P. R., \& Marin, E. B. (1997). Computational mechanics for metal deformation processes using polycrystal plasticity. In Advances in applied mechanics (Vol. 34, pp. 77-169). Elsevier.

[13] Chun, B. K., Jinn, J. T., \& Lee, J. K. (2002). Modeling the Bauschinger effect for sheet metals, part I: theory. International Journal of Plasticity, 18(5-6), 571-595.

[14] Habraken, A. M. (2004). Modelling the plastic anisotropy of metals. Archives of Computational Methods in Engineering, 11(1), 3-96.

[15] Xue, L., \& Wierzbicki, T. (2008). Ductile fracture initiation and propagation modeling using damage plasticity theory. Engineering Fracture Mechanics, 75(11), 3276-3293.

[16] Godest, A. C., Beaugonin, M., Haug, E., Taylor, M., \& Gregson, P. J. (2002). Simulation of a knee joint replacement during a gait cycle using explicit finite element analysis. Journal of biomechanics, 35(2), 267-275.

[17] Maker, B. N., \& Zhu, X. (2000). Input parameters for metal forming simulation using LS-DYNA. Livermore Software Technology Corporation, 4, 43-46.

[18] Carson, Y., \& Maria, A. (1997, December). Simulation optimization: methods and applications. In Proceedings of the 29th conference on Winter simulation (pp. 118-126). IEEE Computer Society.

[19] Swisher, J. R., Hyden, P. D., Jacobson, S. H., \& Schruben, L. W. (2000). A survey of simulation optimization techniques and procedures. In 2000 Winter Simulation Conference Proceedings (Cat. No. 00CH37165) (Vol. 1, pp. 119-128). IEEE.

[20] Wang, J. (2001). Simulation of landmine explosion using LS-DYNA3D software: benchmark work of simulation of explosion in soil and air (No. DSTO-TR-1168). Defence science and technology organisation canberra (Australia).

[21] Wang, L., Basu, P. K., \& Leiva, J. P. (2004). Automobile body reinforcement by finite element optimization. Finite Elements in Analysis and Design, 40(8), 879-893.

[22] Parthasarathy, V. N., \& Kodiyalam, S. (1991). A constrained optimization approach to finite element mesh smoothing. Finite Elements in Analysis and Design, 9(4), 309-320.

[23] Crawford, R. P., Rosenberg, W. S., \& Keaveny, T. M. (2003). Quantitative computed tomography-based finite element models of the human lumbar vertebral body: effect of element size on stiffness, damage, and fracture strength predictions. Journal of biomechanical engineering, 125(4), 434-438.

[24] Elmarakbi, A. M., Hu, N., \& Fukunaga, H. (2009). Finite element simulation of delamination growth in composite materials using LS-DYNA. Composites Science and Technology, 69(14), 2383-2391.

[25] Hughes, T. J., Liu, W. K., \& Zimmermann, T. K. (1981). Lagrangian-Eulerian finite element formulation for incompressible viscous flows. Computer methods in applied mechanics and engineering, 29(3), 329-349.

[26] Belytschko, T., Lin, J. I., \& Chen-Shyh, T. (1984). Explicit algorithms for the nonlinear dynamics of shells. Computer methods in applied mechanics and engineering, 42(2), 225-251.

[27] Ls-Dyna Theoretical Manual. (1998). Livermore Software Technology Corporation.

[28] Mete, O. H. (2007). Sac levhaların şekillendirilebilirliğine etki eden değişkenliklerin incelenmesi. Doktora Tezi, Sakarya Üniversitesi.

[29] Holloman, J. H. (1945). Tensile Deformation, Transactions of the American Institue of Mining and Metallalurgical Engineers, 162:268-290.

[30] Hill, R. (1948). A theory of the yielding and plastic flow of anisotropic metals, Proc. Roy. Soc. London, $281-297$.

[31] Barlat, F., Lian, J. (1989). Plastic behaviour and stretchability of sheet metals (Part I): A yield function for orthotropic sheet under plane stress conditions, International Journal of Plasticity, 5:51-56.

[32] Yoshida, F., \& Uemori, T. (2002). A model of large-strain cyclic plasticity describing the Bauschinger effect and workhardening stagnation. International journal of plasticity, 18(5-6), 661-686.

[33] Akpınar, M., Esener, E., Ercan, S., Özsoy, M., \& Fırat, M. (April-2012) Trip600 Çeliğinin Kare Kesit Çekilebilirliğinin Sonlu Elemanlar Tahmini. In proceedings of International Iron \& Steel Symposium, Karabük, Turkey.

[34] Harpell, E. T., Worswick, M. J., Finn, M., Jain, M., \& Martin, P. (2000). Numerical prediction of the limiting draw ratio for aluminum alloy sheet. Journal of Materials Processing Technology, 100(1-3), 131-141. 